NBER WORKING PAPER SERIES

\title{
FOREIGN CAPITAL AND ECONOMIC GROWTH
}

\author{
Eswar S. Prasad \\ Raghuram G. Rajan \\ Arvind Subramanian \\ Working Paper 13619 \\ http://www.nber.org/papers/w13619
NATIONAL BUREAU OF ECONOMIC RESEARCH
1050 Massachusetts Avenue
Cambridge, MA 02138 \\ November 2007
}

We are grateful to Menzie Chinn, Josh Felman, Olivier Jeanne, Gian Maria Milesi-Ferretti, Dani Rodrik, Thierry Tressel, and participants at the Federal Reserve Bank of Kansas City meetings at Jackson Hole and the Brookings Panel, especially our discussants Susan Collins and Peter Henry, for helpful comments and discussions. We are also grateful to the editors of the Brookings Papers on Economic Activity, William Brainard and George Perry, for constructive comments. We thank Manzoor Gill, Ioannis Tokatlidis, and Junko Sekine for excellent research assistance. The views expressed herein are those of the author(s) and do not necessarily reflect the views of the National Bureau of Economic Research.

(C) 2007 by Eswar S. Prasad, Raghuram G. Rajan, and Arvind Subramanian. All rights reserved. Short sections of text, not to exceed two paragraphs, may be quoted without explicit permission provided that full credit, including (C) notice, is given to the source. 
Foreign Capital and Economic Growth

Eswar S. Prasad, Raghuram G. Rajan, and Arvind Subramanian

NBER Working Paper No. 13619

November 2007

JEL No. E2,F3,F4,O4

\begin{abstract}
We document the recent phenomenon of "uphill" flows of capital from nonindustrial to industrial countries and analyze whether this pattern of capital flows has hurt growth in nonindustrial economies that export capital. Surprisingly, we find that there is a positive correlation between current account balances and growth among nonindustrial countries, implying that a reduced reliance on foreign capital is associated with higher growth. This result is weaker when we use panel data rather than cross-sectional averages over long periods of time, but in no case do we find any evidence that an increase in foreign capital inflows directly boosts growth. What explains these results, which are contrary to the predictions of conventional theoretical models? We provide some evidence that even successful developing countries have limited absorptive capacity for foreign resources, either because their financial markets are underdeveloped, or because their economies are prone to overvaluation caused by rapid capital inflows.
\end{abstract}

Eswar S. Prasad

Cornell University

eswar.prasad@cornell.edu

Raghuram G. Rajan

Graduate School of Business

University of Chicago

5807 South Woodlawn Avenue

Chicago, IL 60637

and NBER

rajan@chicagogsb.edu
Arvind Subramanian

International Monetary Fund

700 19th Street, N.W.

Washington, DC 20431

asubramanian@imf.org 
In one of his most memorable and widely quoted passages, John Maynard Keynes extolled the virtues not only of trade integration but also of financial integration when he wrote, in 1920, of the fabled Englishman who could "adventure his wealth in. . . new enterprises of any quarter of the world, and share, without exertion or even trouble, in their prospective fruits and advantages." Consistency was, of course, not a Keynesian virtue, and in 1933, in one of his less quoted passages, Keynes's musings on globalization turned more melancholy, even skeptical: "I sympathize with those who would minimize, rather than with those who would maximize, economic entanglement among nations. Ideas, knowledge, science, hospitality, travel — these are the things which should of their nature be international. But let goods be homespun whenever it is reasonably and conveniently possible. . ." He reserved his deepest skepticism for financial globalization, warning, "and, above all, let finance be primarily national."

Which Keynes was right? the Keynes of 1920 or the Keynes of 1933? And why? Or, to put it more mundanely, does foreign capital play a helpful, benign, or malign role in economic growth? The question has fueled passionate debates among economists, policymakers, and members of civil society. It has gained importance in recent years because of the curious, even seemingly perverse, phenomenon of global capital flowing "uphill" from poorer to richer countries. But it has economic relevance beyond the current conjuncture because it goes to the heart of the process of development and the role of foreign capital in it. It also has enduring policy relevance as developing countries try to decide whether to open themselves up more to financial globalization, and if so, in what form and to what degree.

We undertake an empirical exploration of this question, beginning with some stylized facts that motivate our analysis. The current account balance, which is equivalent to a country's saving less its investment, provides a summary measure of the net amount of capital, including private and official capital, flowing in or out of a country. ${ }^{3}$ Figure 1 shows that net global cross-border financial flows, measured as the sum, relative to world GDP, of national current account

\footnotetext{
${ }^{1}$ Keynes (1920, p. 11).

${ }^{2}$ Keynes (1933).

${ }^{3}$ A current account surplus has to equal the sum of the following: net private and official outflows of financial capital (this includes debt and nongrant aid, but not remittances, which should properly be reflected in the current account itself); net errors and omissions (a positive number could, for instance, represent capital flight through unofficial channels); and net accumulation of international reserves by the government (typically the central bank). Thus the current account surplus summarizes the net amount of capital flowing out of the country in a given period or, equivalently, the excess of domestic saving over domestic investment in that period; correspondingly, a current account deficit summarizes net capital flowing in or, equivalently, the excess of domestic investment over domestic saving.
} 
surpluses of countries that have surpluses, has been more or less steadily increasing over the last three and a half decades. Although financial globalization was also well advanced in the era leading up to World War I, ${ }^{4}$ there appear to be some important differences in the current episode: today's globalization involves a greater number of countries; not only are net flows sizable, but there are large flows in each direction as well; and these flows encompass a wider range of more sophisticated financial instruments. But it is the apparent perversity in the direction of flows that is most characteristic, and most puzzling, about the globalization of today. ${ }^{5}$

In the benchmark neoclassical model, capital should flow from rich countries with relatively high capital-labor ratios to poor countries with relatively low ratios. Yet, as the top panel of figure 2 suggests, the average income per capita of countries running current account surpluses (with income measured relative to that of the richest country in that year, and with countries weighted by their surpluses in calculating the average) has been trending downward. Correspondingly, the average relative income per capita of deficit countries, weighted in the analogous way, has trended upward. Indeed, in this century the relative income per capita of the surplus countries has fallen below that of the deficit countries. Not only is capital not flowing from rich to poor countries in the quantities the neoclassical model would predict-the famous paradox pointed out by Robert Lucas ${ }^{6}$ - but in the last few years it has been flowing from poor to rich countries. However, this is not a new phenomenon. In the late 1980s as well, the weighted average relative income per capita of surplus countries was below that of deficit countries.

Nor is the pattern entirely driven by the large U.S. current account deficit and the large Chinese surplus. The bottom panel of figure 2, which excludes these two countries, still shows a narrowing of the difference in weighted-average income between surplus and deficit countries by 2005, not the widening that would be predicted in an increasingly financially integrated world under a strict interpretation of the benchmark neoclassical model. ${ }^{7}$

The Lucas paradox has many potential explanations. The risk-adjusted returns to capital investment may not be as high in poor countries as their low capital-labor ratios suggest, either

\footnotetext{
${ }^{4}$ See Obstfeld and Taylor (2004) for example.

${ }^{5}$ See, for example, Bernanke (2006).

${ }^{6}$ Lucas (1990).

${ }^{7}$ Excluding the oil-exporting countries does not alter the basic patterns in figure 2 (not shown). We also constructed similar graphs using initial (1970) relative income, rather than relative income in each period, in order to take out the effects of income convergence. This, too, makes little difference to the shapes of the plots.
} 
because they have weak institutions, ${ }^{8}$ or because physical capital is costly in poor countries, ${ }^{9}$ or because poor country governments have repeatedly defaulted on their debt finance. ${ }^{10}$ But there is a deeper paradox in the data: it seems that foreign capital does not flow even to those poor countries with more rapidly growing economies, where, by extension, the revealed marginal productivity of capital (and probably creditworthiness) is high. ${ }^{11}$ Pierre-Olivier Gourinchas and Olivier Jeanne argue that, among developing countries, capital should flow in greater amounts to those that have grown the fastest, that is, those likely to have the best investment opportunities. ${ }^{12}$ But does it? Figure 3 divides nonindustrial countries into three equally sized (by aggregate population) groups, plus China and India each handled separately, and computes cumulative current account deficits for each group, in dollars deflated by the U.S. consumer price index. The top panel of figure 3 indicates that, over 1970-2004, as well as over subperiods within that range, net foreign capital flows to relatively rapidly growing developing countries have been smaller than those to the two slower-growing groups. In fact, China, the fastest-growing developing country, runs a surplus in every period. During 2000-04 the pattern is truly perverse: China, India, and the highgrowth and medium-growth groups all exported significant amounts of capital, while the lowgrowth group received a significant amount. Gourinchas and Jeanne have dubbed this failure of capital to follow growth the "allocation puzzle," but it is actually a deeper version of the Lucas puzzle itself.

From a pure financing perspective, a composite measure of net flows of all forms of financial capital is the relevant one for examining the role of foreign capital in growth. But of course not all types of capital are the same, in terms of either their allocation or their effects on growth. Indeed, the allocation of capital presents a more nuanced picture when net foreign direct investment (FDI) flows are examined (bottom panel of figure 3). During the most recent

\footnotetext{
${ }^{8}$ Alfaro, Kalemli-Ozcan, and Volosovych (2005).

${ }^{9}$ Hsieh and Klenow (2003); Caselli and Feyrer (2007).

${ }^{10}$ Gertler and Rogoff (1990); Reinhart and Rogoff (2004).

${ }^{11}$ Of course, more-rapid growth could imply greater factor employment and even a lower marginal productivity of capital. However, there is a positive cross-sectional correlation between GDP growth and the Bosworth-Collins (2003) measure of total factor productivity growth (based on the updated version of their dataset that goes through 2003) for the nonindustrial countries in our dataset. Caselli and Feyrer (2007) have constructed a measure of the marginal product of physical capital that corrects for the share of natural capital (land) in the total capital stock of each country and for differences in the relative price of capital across countries. For the countries that are common to our dataset and theirs, average GDP growth is strongly positively correlated with the Caselli-Feyrer measure. This suggests that high-growth countries do have more attractive investment opportunities.

${ }^{12}$ Gourinchas and Jeanne (2006a); the same authors also provide evidence of a negative correlation between capital inflows and investment rates.
} 
period (2000-04), net FDI flows do not follow growth, but in the other periods they do (except in the case of India), with the fastest-growing group of nonindustrial countries receiving the most FDI over the period 1970-2004, and China receiving almost as much. This suggests that fast-growing countries do have better investment opportunities, which is why they attract more FDI. Yet they do not utilize more foreign capital overall, and, again, China is a net exporter of capital.

The above figures show that capital does not flow to poor countries, at least not in the quantities suggested by theory. But does a paucity of foreign capital hurt a country's economic growth? Do those poor countries that can fund investment with the greatest quantity of foreign capital grow the most? Of course, growth in steady-state equilibrium will come primarily from increases in total factor productivity, which could stem from the use of foreign capital. But for poor, capital-starved countries that are far from the steady state, and where investment in physical capital is constrained by the low level of domestic saving, growth can also come simply from additions to domestic resources that enable these countries to reach the steady state faster. So does foreign capital help poor countries grow, either by advancing the stock of knowledge and productivity of the economy or by augmenting scarce domestic resources? This question is at the heart of the debate over whether financial integration has direct growth benefits for developing countries. ${ }^{13}$

A small step toward the answers can be taken by looking at the correlation between growth and the current account balance over the period 1970-2004 for roughly the same sample of nonindustrial countries recently analyzed by Barry Bosworth and Susan Collins (figure 4). ${ }^{14}$ The correlation is positive, not negative as one might have expected: nonindustrial countries that rely less on foreign capital seem to grow faster. ${ }^{15}$

But this might be taking too long run a view. What has happened over specific subperiods in the last three and a half decades? Figure 5 plots the results of nonparametric, Lowess regressions of

\footnotetext{
${ }^{13}$ Henry (2006) argues correctly that the financing provided by foreign capital can have permanent effects on the level of income but only temporary effects on its rate of change. But for the not-so-long horizons examined in this paper, and given how far developing countries are from their steady states, transitional and permanent effects are probably indistinguishable in the data, making the growth effects from additional investment a reasonable focus of inquiry.

${ }^{14}$ The sample differs from that of Bosworth and Collins in that it omits Bangladesh, Guyana, and Taiwan; the countries are listed in appendix table A-1.

${ }^{15}$ A more negative current account balance indicates larger net inflows of foreign capital. A positive current account balance indicates a net outflow of capital.
} 
economic growth on the current account for the entire sample of nonindustrial countries (plus Bangladesh) for four subperiods: the 1970s, the 1990s, 1985-97, and 1999-2004. ${ }^{16}$ The 1985-97 period is probably the golden era of financial integration in recent times, and the period 19992004 is considered distinctive because of the reserves buildup in some Asian countries in the aftermath of the crises there. The figure shows that the puzzling positive correlation between the current account and growth is absent in the 1970s: the line for that decade slopes downward over most of its range. In every period since then, the slopes are positive over most of their range and almost uniformly positive in the range of current account deficits. There is less uniformity in the range of current account surpluses. It does not appear that our core results are simply an artifact of the long time period that we consider.

Figure 6 offers a clue to the direction this paper will be heading in. The figure splits the sample of nonindustrial countries into four groups depending on whether their ratios of investment to GDP and of the current account balance to GDP are above or below the median. Countries with higher investment are seen to fare better (have faster growth of GDP per capita) than those with lower, which is not surprising. What is noteworthy is that countries that had high investment ratios and lower reliance on foreign capital (smaller current account deficits, or larger surpluses) grew faster - on average, by about 1 percent a year - than countries that had high investment but also relied more on foreign capital.

The remainder of the paper starts by placing figure 4 on a firmer footing: we show that, among nonindustrial countries, there is a significantly positive correlation between current account balances (surpluses, not deficits) and growth, even after correcting for standard determinants of growth. The correlation is quite robust: it is evident in cross-sectional as well as in panel data, it is not very sensitive to the choice of period or countries sampled, it cannot be attributed just to aid flows, and it survives a number of other robustness tests. Even the most conservative interpretation of our finding - that there is no negative correlation for nonindustrial countries between current account balances and growth, or equivalently, that developing countries that have relied more on foreign finance have not grown faster in the long run, and have typically grown more slowly - runs counter to the predictions of standard theoretical models.

In an interesting contrast, we find that, among industrial countries, those that rely more on

\footnotetext{
${ }^{16}$ The Lowess procedure estimates a locally weighted regression relationship between the dependent variable and the explanatory variable. It thus allows us to estimate a smoothed, nonparametric relationship between the two.
} 
foreign finance do appear to grow faster. This difference will need to be taken into account in sifting through possible mechanisms that could explain the correlation for nonindustrial countries.

We explore two, not mutually exclusive, explanations for our main finding. First, it is possible that, when facing improved domestic investment opportunities and associated higher incomes, poor countries do not have corporations or financial systems that can easily use arm's length foreign capital to ramp investment up substantially. Indeed, we show that countries with underdeveloped financial systems are especially unlikely to be able to use foreign capital to finance growth.

At the same time, poor countries that are growing rapidly are likely to generate substantial domestic saving, because the persistence of household consumption habits is likely to mean that consumption does not respond quickly to higher incomes - a possibility accentuated by the inability of households in these countries to use the financial system to borrow and consume against expected future income. Thus, with both investment and consumption constrained by weaknesses in the domestic financial system, fast-growing poor countries may not be able to utilize foreign capital to finance growth.

A more pessimistic view sees foreign capital as not just ineffective but actually damaging: when it flows in, it leads to real overvaluation of the currency, further reducing the profitability of investment beyond any constraints imposed by an inadequate financial system. Indeed, by stifling the growth of manufacturing exports, which have proved so crucial to facilitating the escape of many countries from underdevelopment, the real overvaluation induced by foreign inflows can be particularly pernicious. We show that foreign capital can indeed cause overvaluation, which in turn has a detrimental effect on manufacturing exports and overall growth.

These two views of foreign capital-that poor countries have little ability to absorb it, especially when provided at arm's length, and that when it does flow in, it could lead to overvaluation, which hurts competitiveness - are not mutually exclusive. Indeed, an underdeveloped financial system is more likely to channel foreign capital not to potentially highly productive but hard-to-finance investment in the tradable manufacturing sector, but rather to easily collateralized nontradeable investments such as real estate. Thus financial underdevelopment, and underdevelopment more generally, could exacerbate foreign capital's contribution to a rise in costs in the nontraded sector, and to overvaluation.

Moreover, consistent with the relationship we have posited between financial 
development and overvaluation, we do not find evidence of a similar effect of capital inflows on overvaluation in industrial countries. We do find that the ability to avoid overvaluation is helped by favorable demographics, namely, a rapidly growing labor force relative to the population, which provides a relatively elastic supply of labor. Favorable demographics thus plays a key role in generating saving, but also in providing the microeconomic basis for sustaining competitive exchange rates.

The critics of capital account openness point to yet another reason countries may (or ought to) actively avoid foreign capital, namely, the broader risks, including that of inducing greater economic volatility, and especially that of financial or balance of payments crisis. There is little systematic evidence, however, that capital mobility by itself can precipitate crises. ${ }^{17}$ Moreover, even though financial openness does seem to induce additional macroeconomic volatility, which in general is not conducive to promoting investment and growth, there is some evidence that volatility resulting from greater financial (or trade) openness by itself is not destructive to longrun growth, compared with volatility induced by other factors. ${ }^{18}$ Hence volatility is by itself unlikely to be a major explanation for our results, although this deserves more scrutiny in future work. We do not pursue this further here.

Our paper builds upon the vast and growing literature on financial integration and growth, ${ }^{19}$ although this literature has largely focused on measures of financial integration or narrow measures of capital inflows rather than on current account balances. A sizable literature looks separately at the relationship between saving and investment, on the one hand, and growth on the other. Hendrik Houthakker, Franco Modigliani, and Christopher Carroll and David Weil have shown a large positive correlation between saving and growth in a cross section of countries. ${ }^{20}$ But this does not necessarily mean a positive correlation between growth and the current account, because investment in high-saving countries could also be higher. Indeed, Philippe Aghion, Diego Comin, and Peter Howitt see high domestic saving as a prerequisite for attracting foreign saving (and hence for a current account deficit). ${ }^{21}$ Gourinchas and Jeanne conclude that poorer countries are poor because they have lower productivity or more distortions than richer countries, not because capital is scarce in them-the implication being

\footnotetext{
${ }^{17}$ See Edwards (2005) and Glick, Guo, and Hutchison (2006).

${ }^{18}$ Kose, Prasad, and Terrones (2006).

${ }^{19}$ (2006) and Kose and others (2006) provide surveys.

${ }^{20}$ Houthakker (1961), Modigliani (1970), and Carroll and Weil (1994).

${ }^{21}$ Aghion, Comin, and Howitt (2006).
} 
that access to foreign capital by itself would not generate much additional growth in these countries. $^{22}$

In addition to Gourinchas and Jeanne, our paper is related to that of Joshua Aizenman, Brian Pinto, and Artur Radziwill, ${ }^{23}$ who construct a "self-financing" ratio for countries in the 1990s and find that countries with higher ratios grew faster than countries with lower ratios. However, the connection of capital flows to growth seems to be more than just the connection through financing. If financing were all that mattered, because it expands the resource envelope, then net foreign liability positions would be positively correlated with growth. As we will later show, the opposite is true: positive net foreign asset positions are positively associated with growth. Moreover, although fast-growing countries do absorb some forms of capital inflows such as FDI, on net they rely little on foreign capital. This suggests that the full explanation for the relationship between growth and foreign capital inflows has to go beyond financing.

Finally, a broad methodological point. Throughout this paper we will employ a variety of data sources, disaggregated in different dimensions, for our empirical analysis. Although our core correlation will be established at the cross-sectional level, we will also exploit time-series variation to confirm the main finding as well as to substantiate the channels through which some of the effects of foreign capital work. The panel data allow us to try and deal with endogeneity issues, albeit in a rather mechanistic fashion. It is still difficult, even using the panel, to disentangle some of these effects - especially the relationship between financial development and capital inflows - in macroeconomic data, and so we complement our analysis by using industry-level data. We do not of course regard the latter as conclusive, since by construction they cannot account for general equilibrium effects. But the industry-level evidence does allow us to make progress in addressing the endogeneity that plagues some of the cross-country regressions, since we can directly control for countrywide shocks and exploit the cross-industry variation within each country. These results suggest a relationship between foreign capital and growth that is far more nuanced and complex than is suggested by traditional theory.

Ultimately, what we offer are a set of strikingly robust correlations that run counter to the immediate predictions of conventional theoretical models, and a set of plausible explanations for these correlations that are buttressed by various types of evidence. Although this evidence may

\footnotetext{
${ }^{22}$ Gourinchas and Jeanne (2006b).

${ }^{23}$ Aizenman, Pinto, and Radziwill (2004).
} 
not be conclusive, we hope it will set the stage for progress on the theoretical front that will help get a better handle on these correlations, as well as explanations for the patterns we have detected in the data.

\section{The Relationship between Foreign Capital and Growth}

We begin by reviewing the textbook model of how foreign capital inflows should affect economic growth in a country that is open to them. We then proceed to test the model's implications in cross-sectional regressions, check the robustness of the findings, and further confirm the results in regressions using panel data for the same sample of countries.

\section{The Textbook Theory}

The textbook model plots domestic saving and investment against the real interest rate (figure 7). ${ }^{24}$ When the economy is closed to foreign capital, equilibrium is at point $B$ with the interest rate given by $r_{d o m}$. When the economy is opened and the capital account is liberalized (or frictions impeding the flow of foreign capital are reduced), investment increases to point $C$, with the increase in investment financed more than fully by foreign saving (the current account deficit). In this world, increases in capital inflows, as impediments come down, result in a steady movement of domestic interest rates toward world interest rates $\left(r^{*}\right)$, and thus in higher investment and faster growth.

Also, given investment, the extent of utilization of foreign saving should have no effect on growth - it really does not matter whether investment is financed by domestic or foreign capital. The question we now turn to is whether these predictions are borne out in the data.

\section{Financial Integration and Growth}

We begin by testing the relationship between financial integration and growth. Since the traditional textbook model focuses on foreign capital as an aggregate source of financing, we will examine aggregate capital inflows, that is, the current account balance, in what follows.

\footnotetext{
${ }^{24}$ This discussion draws upon Rodrik (2006).
} 
Of course, different types of flows could well have different consequences. The literature has noted that FDI could be an important source of technology transfer as well as of finance. Also, debt and equity flows could have different implications for a country's macroeconomic volatility. The literature has therefore used a variety of measures of financial integration, including policy or de jure measures but also de facto measures based on actual capital movements in terms of stocks and flows. ${ }^{25}$ We will present some robustness checks based on these alternatives, but our core measure will be the current account balance, which has the advantage of being related to macroeconomic variables such as saving, investment, and the exchange rate.

Let us start by placing the correlation between the current account balance and growth depicted in figure 4 on firmer ground. Table 1 presents our core regression results, which build on the work of Bosworth and Collins. ${ }^{26}$ The dependent variable is the annual average growth rate of purchasing power parity-adjusted GDP per capita over 1970-2004, taken from the Penn World Tables (version 6.2). We include the following controls in the standard specification: log of initial (1970) GDP per capita, initial-period life expectancy, initial-period trade openness (the SachsWarner measure), ${ }^{27}$ the fiscal balance, a measure of institutional quality, and dummy variables for sub-Saharan African countries and oil exporters.

When we estimate the above equation using data for the full nonindustrial country sample from Bosworth and Collins (regression 1-1), the coefficient on the current account balance is positive and tightly estimated, suggesting that countries tha $t$ rely less on foreign financing (that is, run smaller current account deficits) grow faster. The coefficient estimate suggests that a 1-percentage-point increase in the current account balance (a smaller deficit or a larger surplus) is associated with approximately a 0.1-percentage-point improvement in the growth rate.

Regression 1-2 drops three outliers from the Bosworth-Collins sample of countries, and regression 1-3 drops, in addition, all countries receiving aid flows that, on average, exceed 10 percent of their GDP. In regression 1-4 the sample is the same as in regression 1-2, but the current account is measured net of aid. In all cases the coefficient is positive and significant. Regressions 1-3 and 1-4 provide reassurance that the results are not driven by poor countries

\footnotetext{
${ }^{25}$ Kose and others (2006) review these measures and argue that, since de jure ones cannot capture the enforcement and effectiveness of capital controls, they may not be indicative of the true extent of financial integration. Actual capital flows may be more relevant for examining the role of foreign capital in the growth process.

${ }^{26}$ Bosworth and Collins(2003). Ourr (Bosworth and Collins, 1999).

${ }^{27}$ Sachs and Warner (1995).
} 
receiving large official aid flows. Since we control for net government saving in all our regressions, our current account coefficient can be interpreted as the marginal effect of private saving on growth, conditional on the level of government saving. In sum, the coefficient estimate is the opposite of that predicted by the standard textbook model postulated earlier.

In what follows we focus on the intermediate sample that excludes the three outliers (we will call this our "core sample"), referring to the other samples only when the results are qualitatively different. Given that current account balances, averaged over a long period, should be directly related to the stock of foreign assets, we check the relationship between growth and the stock position. ${ }^{28}$ In regression 1-5 we replace the current account with the net foreign asset position and find, consistent with the core result, that it is positively correlated (although not statistically significantly) with growth: countries that have accumulated assets over time have grown faster. Regression 1-6 splits the net asset position into gross assets and gross liabilities positions, and we find that the former is positively and significantly related to growth, whereas the latter is negatively but not significantly related to growth.

If, in fact, the binding constraint for countries in our sample is domestic resources, as in the textbook model, larger current account deficits should foster growth by augmenting investment. But the separate inclusion of domestic investment in the regression equation should greatly diminish the coefficient on the current account: conditional on investment, the split between domestic and foreign saving should not matter. Interestingly, however, as regression 1-7 indicates, the inclusion of the investment-GDP ratio barely changes the coefficient on the current account from that in regression 1-2, even though the coefficient on the investment-GDP ratio has the expected positive sign and is almost statistically significant at conventional levels (thus suggesting that mismeasurement of investment is unlikely to be the explanation). ${ }^{29}$ More domestic saving financing a given quantum of investment seems to be positively correlated with growth, a formalization of the result depicted in figure 6. By contrast, when we replace the investmentGDP ratio with the saving-GDP ratio (regression 1-8), the coefficient on the current account loses statistical significance and indeed turns negative. The saving-GDP ratio has the expected significantly positive coefficient. Thus the evidence suggests that the correlation between the current account and growth is positive and stems largely from a relationship between domestic

\footnotetext{
${ }^{28}$ These stock measures have been constructed by Lane and Milesi-Ferretti (2006).

${ }^{29}$ See Bosworth and Collins (2003), who argue that growth in the capital stock is a better measure than the investment-GDP ratio for the purposes of growth accounting and regressions.
} 
saving and growth, and not negative as in the more traditional view that foreign capital permits capital-constrained poor countries to expand domestic investment and thereby increase growth. ${ }^{30}$

\section{Robustness}

Before turning to explanations, we report in table 2 some important robustness checks. First, we estimated the core specification over a different time period, 1985-97, considered a golden age for financial globalization because it was marked by a surge in flows without any significant increase in crises (the exception being the Mexican crisis of December 1994, which was limited in its fallout). The current account coefficient (regression 2-1) remains positive and significant, and, interestingly, the magnitude is over twice that for the period 1970-2004 (regression 1-2).

Although we have established a general pattern for nonindustrial countries, it is worth asking whether the pattern also is present for more economically advanced countries. We revert to the 1970-2004 time period and add industrial countries to the sample. We allow the coefficients on the current account to differ for industrial countries. It turns out (regression 2-2) that the coefficient on the current account balance for industrial countries is significantly different from that for nonindustrial countries and negative overall $(-0.20+0.11=-0.09)$, suggesting that industrial countries that run larger current account deficits experience more growth.

If we restrict ourselves to the period 1990-2004, we can also include economies in transition from socialism and estimate separate coefficients for them. Although the pattern of coefficients for industrial countries is as before (regression 2-3), the transition countries resemble industrial countries in that current account surpluses are negatively correlated with growth; that is, larger inflows of foreign capital boost growth. The phenomenon we have identified thus seems to be

\footnotetext{
${ }^{30}$ We test in appendix table A-2 whether there is a relationship between financial integration and growth, using the measures of integration that have conventionally been used in the literature. We find, consistent with Kose and others (2006), no relationship, in our sample of countries, either between GDP growth and the level of financial openness, whether measured by stocks or by flows, or between GDP growth and changes in these measures. There is weak evidence that FDI, which is qualitatively different from other flows in bringing in technology, is positively correlated with growth (see Borensztein, De Gregorio, and Lee, 1998). We also tested whether the trade balance (as opposed to the current account balance) is the prime driver (results are available from the authors). It turns out that the trade balance, defined as net exports of goods and nonfactor services, is positively correlated with growth, but not statistically significantly so, and the magnitude of the correlation is smaller than that between the current account balance and growth. Clearly, there are elements in the current account balance (including factor incomes and transfers) that add to its explanatory power. For nonindustrial countries, these items can be quite large.
} 
largely a nonindustrial, non-transition country phenomenon. ${ }^{31}$ The additional value of this result is that it indicates we are not simply picking up some hitherto unnoticed mechanical or accounting relationships in macroeconomic data that link current accounts positively to growth.

Finally, we check whether our results are robust to the inclusion of demographic variables, a key determinant of saving. When we include the ratio of the working-age population to total population in the baseline regression 1-2, the coefficient on the current account is reduced by about 30 percent, while the coefficient on the working-age population ratio is positive and highly statistically significant (regression 2-4). This suggests that something associated with domestic saving is partly responsible for the results we find, a point that was also evident earlier.

There is, however, one key concern. The time horizon we have focused on is the long run, spanning the thirty-five years between 1970 and 2004. Perhaps we are picking up not a crosssectional result but rather a time-series result: it may be that successful countries started poor and ran large deficits, but eventually became rich enough to run surpluses. Averaged over a long period, successful countries have had rapid growth and low average deficits, while the unsuccessful have grown slowly and still appear to be running deficits. Thus the long-run relationship might be obscuring a pattern over time that is analytically quite different.

One way to get at this is to look at growth over short periods. Figure 8 plots the current account-GDP ratio over time for countries that experienced growth spurts, ${ }^{32}$ differentiating their performance before and during the growth spurt. On average, current account balances increase (or, put differently, current account deficits narrow) around the beginning of a growth spurt (top panel). The bottom panel shows saving growing faster than investment in these same countries during the same period. In other words, as they move from slow to sustained faster growth, countries also reduce the foreign financing of domestic investment. It is noteworthy that the turnaround in the current account balance is starker when we exclude, in figure 9, the three industrial countries (Ireland, Portugal, and Spain) from the group of sustained rapid growers. This is also consistent

\footnotetext{
${ }^{31}$ Abiad, Leigh, and Mody (2007) find that current account balances are negatively correlated with growth among European countries, including a small group of transition countries. Their work is useful in pointing out that the correlation for transition economies is different from that for other nonindustrial economies, a fact we verify above.

32 These are growth spurts that occurred after 1970 and were followed by sustained growth, as identified by Hausmann, Pritchett, and Rodrik, (2005).
} 
with our findings on the differences in the experiences of the industrial and developing countries. ${ }^{33}$

\section{Panel Evidence}

Another way to confirm that we are not picking up a phenomenon inherent in the life cycle of countries is to turn to panel data and examine growth over shorter periods. ${ }^{34}$ This is important for other reasons also. As a matter of robustness, it is always useful to check whether the observed relationship between countries also holds within countries. If there were a discrepancy between the panel and the cross-sectional evidence, it would call for caution in interpretation. Another reason for doing panel estimations is that they help address, albeit imperfectly, the problem of omitted variables and endogeneity that afflict pure cross sectional estimations. The inclusion of country fixed effects in the panel controls for unobservable heterogeneity between countries. We employ the generalized method of moments (GMM) estimation technique in order to take a stab at dealing with the endogeneity issue, although in a rather mechanistic fashion. ${ }^{35}$

Table 3 reports results of panel regressions estimated on five-year averages of the underlying annual data. To maintain consistency with the cross-sectional results, we use the same controls in each regression in table 3 that we use in the corresponding regression (by

\footnotetext{
${ }^{33}$ This is not to say that all forms of foreign finance fall during growth spurts. Indeed, the average ratio of FDI to GDP rises from an annual average of 0.2 percent in the five years before the initiation of a growth spurt to 0.7 percent in the five years after. Similarly, using the episodes of growth decelerations identified by Jones and Olken (2005), we find that the average FDI-GDP ratio falls from 1.7 percent in the five years before the deceleration to 1 percent in the five years after. But even these increases and decreases are small compared with the changes in domestic saving following a growth spurt or deceleration.

${ }^{34}$ One version of the life cycle model applied to countries has implications for the evolution of current account balances (see the discussion in Chinn and Prasad, 2003). According to this theory, poor countries that open up to foreign capital early in the development process should run current account deficits as they import capital to finance their investment opportunities. Eventually, these countries would become relatively capital rich and begin to run trade surpluses, in part to pay off the obligations built up through their accumulated current account deficits.

${ }^{35}$ GMM estimators come in two flavors. There is the difference-GMM estimator of Arellano and Bond (AB; 1991) and the system-GMM estimator of Blundell and Bond (BB; 1998). In both, identification relies on first differencing and using lagged values of the endogenous variables as instruments. In the AB estimator, lagged levels are used to instrument for the differenced right-hand-side variables, whereas in the BB estimator, the estimated system comprises the difference equation instrumented with lagged levels as in the AB estimator as well as the level equation, which is estimated using lagged differences as instruments. Each estimator has its limitations. The $\mathrm{AB}$ estimator often leads to a weak instruments problem because lagged levels are typically not highly correlated with their differenced counterparts. So, in what follows, we present estimations based on the BB estimator. All specifications include time effects to control for common shocks.
} 
numbered column) in tables 1 and $2 .^{36}$ In regression 3-1 the coefficient on the current account balance is positive and similar in size to that in the cross-sectional regression, although the coefficient is not estimated precisely. In regression 3-2 we drop the three countries that are outliers in the cross section, and the coefficient on the current account increases slightly but remains insignificant. In regression 3-3 we also drop the high-foreign-aid-receiving countries to ensure that our results are not driven by official capital inflows. Now the coefficient increases substantially and is significant at the 5 percent level. Regression 3-4 uses the same sample as in regression 3-2 but nets out aid from the current account balance- the coefficients are similar in the two regressions.

Next, in regression 3-5 we add the domestic investment-GDP ratio as a regressor. The coefficient on this variable is significant, but it does not diminish the estimated coefficient on the current account balance. Regression 3-6 substitutes domestic saving for the investment variable. As in the cross section, this variable is significant and drives the coefficient on the current account balance to zero. Regression 3-7 replaces domestic saving with the share of the working-age population, and regression 3-8 estimates a separate current account coefficient for industrial countries. Although the panel estimates are less precise, the similarity of the coefficient estimates in both the cross-sectional and panel estimations, including when investment and saving are included alternatively as variables, is reassuring for the robustness of the core results. They tend to offer additional support for our finding that foreign capital inflows (current account deficits) and growth are not positively correlated in nonindustrial countries, in contrast to what the standard neoclassical growth model would predict. ${ }^{37}$

What Explains the Observed Relationship between Capital Flows and Growth?

The previous section identified a robust, nonnegative association between current account

\footnotetext{
${ }^{36}$ One methodological point bears mentioning. GMM procedures allow a fair amount of freedom, especially in specifying the lag structure for the instruments. There is a tradeoff: the greater the lags, the more the information that is used. But greater lags can lead to overfitting and weak instrumentation. Two key diagnostics to use in checking for these problems are the Hansen test for overidentifying restrictions and the Arellano-Bond test for serial correlation. When we used the second lag, our results were stronger than reported in the text, but there were occasional problems of overfitting, reflected in very large p-values for the Hansen test. We therefore report results using the third and fourth lags, which are more reassuring in relation to these two diagnostics.

${ }^{37}$ We cannot include data for the transition countries in the panel regressions, as our estimation procedure requires data for at least four time periods for a country to be included in the sample.
} 
balances and long-run growth in nonindustrial countries, which is significantly positive across a number of subsamples and estimation procedures. At no point do we find a negative correlation in this group of countries, as the standard theoretical models might suggest, although we do find such a correlation for industrial and transition countries.

From a saving-investment perspective, the evidence seems to challenge the fundamental premise that investment in nonindustrial countries is constrained by the lack of domestic resources. If that were the case, the correlation between the current account and growth should run through domestic investment. It does not. What explains all this? That is what this section attempts to answer.

\section{Some Conjectures}

Consider the ingredients we already have for an explanation. First, the positive correlation between current accounts and growth is found primarily in poor countries, suggesting that something to do with the structure of poor economies may be responsible. Second, it appears that the correlation runs through domestic saving and not through domestic investment. In other words, investment does not seem to be highly correlated with net capital inflows, suggesting that it is not constrained by lack of resources.

INSTITUTIONAL UNDERDEVELOPMENT. Let us now venture an explanation, which we will put together with a number of ingredients. We know from figures 8 and 9 that income growth spurts in poor countries lead to greater domestic saving. ${ }^{38}$ Theoretical models exist showing that the saving rate could increase even in the face of a persistent increase in income-for example, because of habit persistence in consumption. ${ }^{39}$ The link between income growth and saving in a poor economy could be further strengthened if the relative underdevelopment of the financial sector prevents consumers from borrowing against their anticipated future incomes.

Greater saving does not automatically mean a larger current account surplus or a smaller deficit, because investment could increase more than commensurately. But suppose that poor

\footnotetext{
${ }^{38}$ Bernanke and Gürkaynak (2002) report a positive correlation between productivity growth and saving in a broad sample of countries - they do not break their sample out into different groups of countries based on income.

${ }^{39}$ Carroll and Weil (1994), for instance, show that habit persistence may be one way to reconcile the strong positive correlation between saving and growth, a correlation that runs counter to the predictions of the standard life cycle or permanent income hypothesis. Jappelli and Pagano (1994) build a model showing how financial market imperfections that limit the ability to borrow against future income could generate a correlation between saving and growth in a fast-growing economy with a low level of financial development.
} 
countries also suffer from capacity constraints in ramping up investment, even in the face of positive productivity shocks, especially if resources have to be invested at arm's length. This could occur because the financial system does not intermediate saving well. ${ }^{40}$ Problems will be particularly acute in the investment of foreign private capital, which by definition is invested at arm's length (apart from FDI). It could also result from weak protection of property rights in poor countries, which militates against the long-gestation, investment-intensive, low-initial-profitability projects that are the most dependent on financing. Again, to the extent that foreign capital does not enjoy the domestic power relationships that substitute for institutional infrastructure such as property rights protection, it may be at a particular disadvantage in financing such projects. ${ }^{41}$

There are some important differences between our explanation and that of Ricardo Caballero, Emmanuel Farhi, and Gourinchas, ${ }^{42}$ who argue that weak financial development and the consequent inadequate supply of reliable financial assets can explain the phenomenon of poorer countries running larger current account surpluses. In these authors' view, for example, developing country households prefer holding foreign bonds to holding domestic financial assets, and this portfolio decision drives local interest rates up and limits domestic investment. In our view domestic households do accumulate domestic financial assets, especially those intermediated through banks, and thus do finance domestic investment. Corporations can also do so through their own saving. Instead it is difficulties in funneling foreign capital into domestic corporate investment that limits the absorption of foreign capital. ${ }^{43}$

In other words, the real difficulty in these countries is not with domestic firms investing internally generated funds or even raising funds from domestic sources such as domestic banks, but with domestic firms raising funds at arm's length, especially from foreigners. Indeed, in growth episodes the firms with the best opportunities are likely to be new, typically private sector, firms that usually are not connected through old ties to the banking system or the government. Because these firms lack the contacts needed to borrow from banks, and because they have difficulty raising money at arm's length from domestic or foreign sources in an

\footnotetext{
${ }^{40}$ Wurgler (2000) provides evidence that underdeveloped financial sectors are unable to reallocate resources to their highest-productivity uses, leading to a mismatch between productivity increases and investment.

${ }^{41}$ See Rajan and Zingales (1998).

${ }^{42}$ Caballero, Farhi, and Gourinchas (2006).

${ }^{43}$ In truth, many developing country households (for example, in China) have been accumulating domestic financial assets in the form of bank deposits. The final holder of foreign assets is often the government, not households. One could argue that households are willing to hold bank deposits only because banks hold central bank paper, which is eventually a claim on foreign bonds, but this seems a tenuous line of reasoning.
} 
underdeveloped financial system, investment is likely to be constrained.

This line of argument can also explain the negative correlation between current accounts and growth for rich countries. Their greater financial and institutional development allows investment to be more responsive to productivity increases. ${ }^{44}$ It also allows citizens to borrow against anticipated future wealth in order to consume. So for industrial (and transition) countries, investment may be significantly more responsive to productivity increases (the primary source of growth in these countries), but saving may be less responsive, than in nonindustrial countries, leading to larger current account deficits.

In this view, foreign capital inflows do not hurt growth in poor countries, but they do not help either. These countries are typically constrained not by resources, but by the investment opportunities that they can profitably exploit using arm's-length finance. Foreign capital is not directly harmful; it simply cannot be used well, especially in investment intensive, low-initial-cashflow, long-gestation projects.

This line of argument is plausible, but its empirical relevance remains open to question. For instance, Gourinchas and Jeanne argue that although frictions in financial markets (for example, underdeveloped financial systems) can result in the current account deficit being less responsive to growth in countries with less developed financial systems, plausible model parameterizations do not lead to the reversal in the sign on the correlation that we find. ${ }^{45}$ Indeed, Aart Kraay and Jaume Ventura construct a plausibly parameterized model which implies that the impact of productivity shocks on a country's current account balance should be related to its initial net liability position. In countries with a net foreign liability position, such as most of the nonindustrial countries in our sample, productivity growth will typically lead to an increase in the current account deficit, not a reduction as we find. ${ }^{46}$

A LESS BENIGN VIEW. The fact that conventional theoretical models, or even recent models that depart from conventional theory (for instance, by positing habit formation in consumption), cannot fully explain our findings suggests the need to explore alternative explanations. The way

\footnotetext{
${ }^{44}$ Glick and Rogoff (1995) showed that country-specific productivity shocks tend to generate investment booms and larger current account deficits (or smaller surpluses) in what were then the Group of Seven leading industrial countries.

${ }^{45}$ Gourinchas and Jeanne (2006a).

${ }^{46}$ Kraay and Ventura (2000). Their argument is based on the intuition that the marginal portfolio allocation decision (how to invest the extra saving generated by income shocks) will resemble the average decision (reflected in the existing net liability stock) unless investment risk is low and domestic investment is highly subject to diminishing returns.
} 
forward may be to take a less benign view of the effects of foreign capital. Recall the textbook model (figure 7) with which we started the last section. Suppose now that foreign financing can have some deleterious effects, over and above its inability to be allocated properly in a country with a weak financial system. In particular, large inflows could lead to an increase in real wages, an appreciation of the currency in real terms, and a fall in the marginal product of investment. Equivalently, the higher domestic consumption that necessitates a greater reliance on foreign finance could fall substantially on nontraded goods, pushing up their price and leading to currency overvaluation. The greater the capacity of a country to expand nontraded goods, the less the overvaluation. Thus, where domestic saving is insufficient, the use of foreign capital to finance investment may further depress the profitability of investment by causing an overvaluation of the currency - a form of what is commonly known as Dutch disease. Countries that rely excessively on foreign capital to fund their investment may find themselves becoming increasingly uncompetitive on the trade front.

The textbook model will then have to be modified, and figure 10 suggests heuristically how this can be done. Suppose foreign capital inflows strengthen the real exchange rate, making potential exports less profitable. This will shift the investment schedule inward, reducing total investment at any interest rate. The size of the shift will depend on the magnitude of the inflows, the responsiveness of the exchange rate to those inflows, and the responsiveness of investment to the change in the exchange rate. One way of depicting the shift in investment is to illustrate what capital inflows would be at alternative levels of the elastic world supply of foreign capital $\left(r^{*}\right)$. Above $r_{\text {dom }}$ there will be no foreign capital inflow, and so the investment schedule will be unaffected. Below $r_{\text {dom }}$ one can trace a new investment schedule at each level of $r^{*}$. This schedule will lie to the left of segment $I_{l}$ because of the negative relationship between inflows and investment that arises from the exchange rate effect. And it will lie further to the left, the lower is $r^{*}$, because inflows increase as $r^{*}$ declines. If the exchange rate response to inflows and the investment response to exchange rate changes are sufficiently strong, the new investment schedule will rotate leftward around point $B$ and be represented by the segment $I_{2}$. In this case, when the country opens up, the new equilibrium at point $D$ is to the left of the old equilibrium $B$. There will be more capital inflows relative to $B$, but lower investment, lower domestic saving, and slower growth, generating the correlation we find in the data. Thus the introduction of distortions to the exchange rate and investment caused by capital inflows can further help account for our findings. 
Finally, an expansionary shift in domestic saving in such an economy (from $S_{1}$ to $S_{2}$ in figure 11) can lead to an expansion of investment and growth. A shift in domestic saving, by reducing foreign inflows at each level of the interest rate, will have a positive effect on investment by reducing the extent of overvaluation. Not only will the saving curve shift right, but there will be an associated rightward shift of the investment curve from $I_{2}$ to $I_{3}$ (because at each level of $r *$ there will be smaller inflows, and hence less overvaluation and greater investment). Note that, in this case, an exogenous shift in domestic saving will increase investment and growth even in a country with a fully open capital account, which would not have happened in a world in which inflows do not distort the exchange rate.

\section{Does Foreign Finance Matter? Evidence from Industry-Level Data}

Let us now see if we can provide any evidence for the details of these explanations. One explanation we have offered is that foreign capital is not a good method of financing investment in countries with underdeveloped financial systems. One way to verify this is to see whether industries that need a lot of finance are relatively better or worse off if the country where they are located gets a lot of foreign capital, and to see how this varies with the country's level of financial development. In a sense this allows us to determine whether foreign capital has a comparative advantage or disadvantage in financing.

The use of industry-level data has another big benefit: it allows us to get around the endogeneity and reverse causality problems that are rampant (and difficult to control for) in country-level data. For instance, even if rapid growth tends to pull in more capital inflows (rather than inflows causing growth), or if growth and inflows are jointly determined by other factors, there is no reason why the effect of inflows on industry-level growth through the financing channel should be different across industries within the same country. Similarly, it is unlikely that growth in a particular industry at this level of disaggregation can be a significant determinant of aggregate capital flows, and so aggregate capital flows can be considered exogenous to an industry's growth. Thus, by exploiting cross-industry variation and controlling for country- and industry-specific factors, we can make some progress toward tackling concerns about endogeneity. (As noted earlier, the potential endogeneity used as an illustration here should lead to a positive correlation between net foreign capital inflows and growth, whereas our cross-country 
results show the opposite correlation.)

RELATIVE INDUSTRY GROWTH. Using the methodology of Rajan and Luigi Zingales, ${ }^{47}$ we first ask whether, correcting for industry-specific and country-specific factors, manufacturing industries that are dependent on outside finance (rather than internally generated cash flows) for funding investment grow faster in countries that get more foreign capital (or are more open to foreign capital). The estimation strategy is to run regressions of the form

$$
G_{i j}=\psi+\zeta_{1}{ }^{\prime} C_{j}+\zeta_{2}{ }^{\prime} I_{i}+\zeta_{3} \operatorname{man}_{i j}+\alpha\left(\text { open }_{j} \times d e p_{i}\right)+\varepsilon_{i j}
$$

where $G_{i j}$ is the annual average rate of growth of value added in industry $i$ in country $j$ over tenyear periods (1980-90, 1990-2000), obtained by normalizing the growth in nominal value added by the GDP deflator; $C_{j}$ is a vector of indicator variables for each country; $I_{i}$ is a vector of indicator variables for each industry; $\operatorname{man}_{i j}$ is the initial-period share of industry $i$ in manufacturing in country $j$ (which controls for convergence-type effects); $\mathrm{open}_{j}$ is "openness to capital flows of country $j$," which is some de facto or de jure measure of the capital account openness of country $j$; $d e p_{i}$ is "dependence of industry $i$ on finance," which is the fraction of investment in that industry that the typical firm could not fund from internally generated cash flows; and $\varepsilon_{i j}$ is the error term. ${ }^{48}$ Dependence is typically high in industries where investment is large and positive cash flows follow only after a lengthy gestation period.

The coefficient of interest for us is $\alpha$. The textbook model would predict that countries that are more open to capital should see financially dependent industries grow relatively faster, and so we would expect the coefficient $\alpha$ to be positive (for tables 4 and 5 we use the current account deficit rather than the current account balance, so that the predicted coefficient is the same as for other measures of capital inflows).

The chief advantage of this strategy is that, by controlling for country and industry fixed effects, the problem of omitted-variables bias or incorrect model specification, which afflicts

\footnotetext{
${ }^{47}$ Rajan and Zingales (1998).

${ }^{48}$ Rajan and Zingales (1998) describe how they calculate the number for the period 1980-89. We calculate a similar number using U.S. corporate data between 1990 and 1998 (after 1998, normal financing behavior would be contaminated by the equity bubble). In computing each industry's dependence on finance for 1990-98, we first compute the dependence on finance of each firm in the industry over the period, truncate outlier firms at the 10th and 90th percentiles, and then average across all firms. We then take the average of the industry's dependence for the 1980s and the 1990s to get our final measure.
} 
cross-country regressions, is diminished. Essentially, we are making predictions about withincountry differences between industries based on an interaction between a country and an industry characteristic. Moreover, as discussed above, because we analyze differences between manufacturing industries, we can rule out factors that would affect manufacturing in a country as a whole as explanations of our results - these factors should not affect differences between manufacturing industries.

THE BASIC REGRESSION. Rajan and Zingales interact the country's level of domestic financial development with the industry's finance dependence. ${ }^{49}$ Before we ask about the role of foreign capital, an immediate question is whether their methodology "works" for this group of countries. We estimate their basic regression including an interaction between the country's domestic creditGDP ratio, our primary proxy for a country's domestic financial development, and the industry's finance dependence. The coefficient on the interaction is positive and statistically significant for both the 1980s and the 1990s, suggesting that it is a reasonable exercise to use this methodology to investigate the role of foreign capital in finance.

We focus on six measures of capital account openness: five de facto measures and one de jure measure. The de facto measures are the ratio of the stock of inward FDI to GDP, the ratio of the stock of inward FDI and portfolio investment to GDP, the net flow counterparts of these two ratios, and the average current account deficit over the period. The de jure measure is taken from Menzie Chinn and Hiro Ito. ${ }^{50}$

We first ran these regressions without controlling for the level of domestic financial development, to get a sense of the unconditional effect of foreign finance (estimates available from the authors). The estimated interaction coefficients are neither uniformly significant nor of the sign expected in the textbook model. Indeed, the results for the 1980s are more mixed, with the coefficient on the current account deficit being negative and significant in the "wrong" direction. The coefficients for the 1990s sample are of the expected sign (with a positive coefficient on the current account deficit interaction) but are significant in only two of the six cases. ${ }^{51}$

THE IMPORTANCE OF DOMESTIC FINANCIAL DEVELOPMENT. It may well be that our specification is not complete. Countries that are more open also have better developed financial

\footnotetext{
${ }^{49}$ Rajan and Zingales (1998).

${ }^{50}$ Chinn and Ito (2006).

${ }^{51}$ To reduce the effect of data errors, all variables are "winsorized" at the 99 percent and the 1 percent level. Standard errors are robust, and we report the estimates when we cluster by country. Results are qualitatively similar when we cluster by industry. These results are available from the authors upon request.
} 
markets. ${ }^{52}$ Financial integration may proxy for financial development. We should therefore include an interaction between our proxies for the country's domestic financial development and an industry's dependence on finance, to check whether the effects of foreign capital persist even after we control for domestic financial development. Our primary proxy for financial development is the ratio of domestic credit to GDP. A second proxy is the country index of the quality of corporate governance (which is available for fewer countries and does not vary across time) ${ }^{53}$

Also, we should check for threshold effects: the benefits of foreign capital may kick in only after a country's domestic financial development exceeds a certain level. ${ }^{54}$ So we include a separate interaction between our measure of foreign capital penetration and an industry's dependence on finance if the country is below the median level of financial development (as measured by the ratio of domestic credit to GDP) in our sample of countries. Since this is a triple interaction, we also have to include all the relevant double interactions. So the final specification is

$$
\begin{aligned}
G_{i j}=\psi & +\zeta_{1}{ }^{\prime} C_{j}+\zeta_{2}{ }^{\prime} I_{i}+\zeta_{3} \text { man }_{i j}+\alpha_{1}\left(\text { open }_{j} \times \text { dep }_{i}\right) \\
& +\alpha_{2}\left(\text { open }_{j} \times \text { dep }_{i} \times \text { bmed }_{j}\right)+\alpha_{3}\left(\text { cred }_{j} \times \text { dep }_{i}\right) \\
& +\alpha_{4}\left(\text { cred }_{j} \times \text { dep }_{i} \times \text { bmed }_{j}\right)+\alpha_{5}\left(\text { gov }_{j} \times \text { dep }_{i}\right) \\
& +\alpha_{6}\left(\text { dep }_{i} \times \text { bmed }_{j}\right)+\varepsilon_{i j},
\end{aligned}
$$

where cred $_{j}$ is the ratio of domestic credit to GDP of country $j$; gov $v_{j}$ is the value of the corporate governance index for country $j$; and $b_{m e d}$ is an indicator variable equal to 1 if country $j$ is below the median ratio of domestic credit to GDP. The other variables are identical to those in equation 1.

If there are threshold effects, so that countries with under developed financial systems cannot utilize foreign capital well to finance investment, we should find $\alpha_{1}$ to be positive and $\alpha_{2}$ negative. Table 4 reports the results from this augmented specification for the 1980s and 1990s cross sections.

The results from this specification are much more stable and offer a consistent picture.

\footnotetext{
${ }^{52}$ Kose and others (2006).

${ }^{53}$ index was constructed by De Nicoló, Laeven, and Ueda (2006).

${ }^{54}$ See Chinn and Ito (2006) and Alfaro and Hammel (2007).
} 
Twenty-one of twenty-four coefficients have the expected sign (that is, expected in the model with threshold effects where we postulate different effects of foreign capital in less financially developed countries), and twelve are significant at conventional levels. The average effect we obtained from estimating equation 1 seems to conceal very different implications for financially developed and financially underdeveloped countries, effects that are visible only by estimating equation 2. In particular, for countries that have above-median levels of financial development, foreign capital aids the relative growth of those industries dependent on finance. In regression 4-7 the coefficient of the interaction term for countries that are above the median level of financial development is about 50 percent higher than the "average" coefficient for the specification in equation 1 (estimates available from the authors upon request).

But for countries below the median for financial development, the effect of foreign capital inflows is diametrically opposite. The sum of the reported interaction coefficients in each specification reflects the marginal effect of foreign capital on the relative growth of dependent industries in countries that have below-median financial development. In eleven out of twelve specifications, the sign on the sum of coefficients suggests that industries dependent on finance grow relatively more slowly as a financially underdeveloped country draws in more foreign capital. Foreign capital seems to hurt rather than help the relative growth of industries dependent on finance in those countries.

Before we turn to interpretation, we present in table 5 our estimates from panel versions of equation 2; the estimates include industry-country dummies in addition to separate country and industry dummies. We use the within-country, within-industry, across-time variation to identify effects. ${ }^{55}$ All the specifications clearly indicate that foreign capital detracts from the relative growth rate of financially dependent industries in countries that are below the median with respect to financial development. By contrast, all the specifications uniformly indicate that domestic financial development is good for the relative growth rate of industries dependent on finance, and especially

\footnotetext{
${ }^{55}$ Relative to the earlier specification, we drop the industry's initial share of manufacturing and the interaction of industry dependence on finance with the country's corporate governance index. The initial share of manufacturing should be absorbed in the industry $\times$ country indicator, and the interaction is not meaningful since neither the corporate governance index nor dependence on finance varies across time. Note that in this panel specification the openness to capital flows varies across time and countries, whereas dependence on external finance varies across industries, which, in the presence of industry-country fixed effects, allows identification within country, within industry, and across time.
} 
so in countries that are below the median level of financial development. ${ }^{56}$

DISCUSSION. Foreign capital may need a developed domestic financial system to be effective, because it may lack access to the informal sources of information and power that allow domestic finance to operate even in an underdeveloped system. For instance, if property rights are not well protected (an element of a sound financial system), foreign capital may shy away from industries that require high long-term investment. Instead, incremental foreign capital may flow into industries that typically do not require high up-front investment and that have high cash flows in the short run, or into nonindustrial sectors that have clearly demarcated, collateralizable assets (such as real estate). This could explain why finance-intensive industries do relatively poorly or, equivalently, why industries that generate high and immediate cash flows with low up-front investment do relatively well, as additional foreign capital flows into countries with underdeveloped financial sectors. In other words, in such countries foreign capital does not come in as a source of financing, but to exploit domestic opportunities that require little financing, or to provide know-how.

Of course, our findings are also consistent with the possibility that foreign capital may actually hamper access to finance. Foreign capital may have to be channeled through domestic intermediaries when the financial sector is underdeveloped, and it may facilitate rather than hinder the formation of domestic financial monopolies, as the strongest domestic intermediaries are further strengthened by access to foreign capital. Foreign capital may also choose (and be able) to cherry-pick the few good opportunities in an underdeveloped country, leaving less incentive for domestic financial institutions to enter or participate. ${ }^{57}$

Note that, in these financially underdeveloped countries, although an increase in foreign capital does not help industries that are dependent on finance, an increase in domestic capital (which is largely what the ratio of domestic credit to GDP represents) is indeed helpful. Perhaps domestic credit institutions can better navigate the pitfalls of an underdeveloped system.

\footnotetext{
${ }^{56}$ The coefficient on the interaction in the panel is negative also for countries with above-median levels of financial development, unlike in the cross-sectional results. One interpretation of this is that the benefits of foreign capital accrue even to financially well developed countries only in the medium run.

${ }^{57}$ Detragiache, Tressel, and Gupta (2006) show that, in poor countries, a stronger foreign bank presence is robustly associated with less credit to the private sector in both cross-sectional and panel tests. In addition, in countries with more foreign bank penetration, credit growth is slower and there is less access to credit. By contrast, they find no adverse effects of foreign bank presence in more advanced countries. Tressel and Verdier (2007) show that, in countries with weak institutions, financial integration leads to greater investment by politically connected firms, with a loss of efficiency. Our findings are not inconsistent with these results.
} 
Perhaps also, more domestic credit reflects, and leads to, a better financial system that can support more credit to financially dependent industries, and eventually from foreign sources.

Finally, one could ask whether domestic financial development is a proxy for development more generally, or for the broader institutions that accompany development. We reestimated the regressions in tables 4 and 5, replacing a country's measure of financial development with the logarithm of its GDP per capita (with additional interactions, where necessary, based on whether a country is below the median on this measure). The coefficient estimates of the triple interaction (available from the authors) were often insignificant and sometimes the opposite of what one might expect. It is not primarily underdevelopment (or the factors accompanying or causing it) that causes foreign capital to be ineffective in nonindustrial countries; instead what matter seem to be factors related to a specific form of underdevelopment, namely, financial underdevelopment.

In sum, the industry evidence can explain why foreign capital may not be an effective source of finance for nonindustrial countries. Although the evidence thus far cannot rule out a benign interpretation of the role of foreign capital, it strongly suggests that if poor countries are seeking to improve financing for industry, instead of just hankering after additional financing in the form of foreign capital, they can reap substantial benefits from focusing on domestic financial development. ${ }^{58}$

\section{Overvaluation, Trade, and Growth}

Let us now turn to the less benign explanation: that capital inflows may lead to an appreciation of the national currency in real terms, which in turn may reduce the profitability of exports and thus reduce investment. The consequences of capital inflows for international competitiveness may then be an important contributing factor to the patterns we observe.

OVERVALUATION AND CAPITAL FLOWS. Simon Johnson, Jonathan Ostry, and Subramanian construct a measure of a country's exchange rate competitiveness, accounting for the Balassa-

\footnotetext{
${ }^{58}$ This argument does not, of course, detract from the possibility that foreign capital has large indirect benefits, including on financial development itself. Some authors point to the beneficial effects of equity market liberalization on growth (for example, Bekaert, Harvey, and Lundblad, 2005, and Henry, 2006). In addition to the problem of timing that the literature notes - such liberalization is typically part of broader macroeconomic reforms that affect outcomes - the countries that liberalize might be the same ones that are typically able to reap the benefits from foreign finance, in part because they have stronger financial sectors. For this reason, our findings need not be inconsistent with the more positive tone of the equity market liberalization literature.
} 
Samuelson effect. ${ }^{59}$ Essentially, the idea is to measure the deviation of a country's exchange rate from purchasing power parity, after accounting for differences in incomes. This deviation we term overvaluation.

The immediate question is whether there is a relationship between overvaluation and capital inflows. In table 6 the dependent variable is our measure of the extent of overvaluation. We include as explanatory variables the ratio of the working-age population to the total population (since a larger working-age population should increase the supply response of an economy to any incipient overvaluation and help contain it) and, to capture financial openness, different measures of capital inflows or the Chinn-Ito de jure measure of openness. Regardless of the type of inflows included, the coefficient is always positive and nearly always significant: the larger the inflows, the less competitive the recipient economy at the current real exchange rate. For the Chinn-Ito de jure measure of openness, however, the coefficient is not significant (regression 6-6), suggesting that only actual flows lead to pressures for real appreciation. ${ }^{60}$

Figure 12 plots the relationship, conditional on the share of the working-age population, between overvaluation and one of the capital flow measures, total net private capital inflows. The figure shows a strong positive relationship and that no outliers are driving the relationship,

If overvaluation in nonindustrial countries as a result of capital inflows is to account for the observed positive relationship between current account balances and growth there, it must be that capital inflows do not cause overvaluation in industrial countries. So in the last two specifications of table 6 we include in the regression an interaction between the industrial country dummy and the relevant flows variable. The results are striking. For example, when we use net private inflows as the relevant capital flow variable, the coefficient on the interaction is negative and significant (regression 6-8), whereas the direct effect is positive; so, for nonindustrial countries, more inflows lead to more overvaluation. The total marginal effect of inflows on overvaluation $(-1,038+826=-212)$ is statistically insignificantly different from zero for

\footnotetext{
${ }^{59}$ Johnson, Ostry, and Subramanian (2007). On the Balassa-Samuelson effect, see Meese and Rogoff (1983). We estimate the following cross-sectional equation for every year since 1960 for the full sample of countries: $\log p_{i}=\alpha$ $+\beta \log y_{i}+\varepsilon_{i}$, where $p$ is the $\log$ of the price level for country $i$ relative to that in the United States, and $y$ is GDP at purchasing power parity. Our measure of overvaluation is then overval $i_{i} \log p_{i}-\left(\alpha\right.$-hat $+\beta$-hat $\left.\log y_{i}\right)$. We average this measure for each country over the relevant period. This measure is also used by Rajan and Subramanian (2005).

${ }^{60} \mathrm{We}$ could run the same regression in a panel context, but there is more reason to expect the real exchange rate to be decoupled from capital flows in the short run; countries can use sterilized intervention, fiscal policy, and other measures to retain influence over the real exchange rate. Unless we can control for these short-run policies, it would be difficult to identify the effect of flows on overvaluation.
} 
industrial countries. The same result holds when we use net FDI inflows as the relevant measure of capital flows (regression 6-7). What this suggests is that overvaluation, and thus the distortion of investment returns caused by the use of foreign saving, may matter far less for industrial countries, which may help explain the positive correlation between their use of foreign saving and growth.

Having established that there is a positive correlation in nonindustrial countries between capital inflows and average overvaluation, let us now ask if such overvaluation has an effect on competitiveness and growth. ${ }^{61}$ If it does, it could explain the negative correlation between capital inflows and growth that we have already documented.

OVERVALUATION AND GROWTH. Table 7 introduces our measure of overvaluation into the core specification of tables 1 and 3, in both the cross section and the panel. In the cross section (regressions 7-1 and 7-2) the coefficient on overvaluation has the expected negative sign and is significant at the 10 percent level. ${ }^{62}$ The coefficient is less negative when we exclude countries receiving high levels of aid. The addition of the share of the working-age population (regression 7-4) also reduces the impact of both the current account and overvaluation. As argued earlier, this may reflect the possibility that exogenous shifts in saving (due to demographic factors) lead to faster growth by way of reduced overvaluation.

In the panel version (in which the sample period is split into five-year subperiods), the coefficient on overvaluation is negative and significant at the 5 percent level for the large sample, both when the share of the working-age population is included (regression 7-8) and when it is not (regression 7-5), but it falls just short of significance $(\mathrm{p} \approx 0.12)$ when the sample is reduced and the working-age population share is omitted (regressions 7-6 and 7-7). ${ }^{63}$ The magnitude of the coefficient in regression 7-6 suggests that, in the short run, a 1-percentage-point increase in the degree of

\footnotetext{
${ }^{61}$ One qualification to this result is that, when we use the current account-GDP ratio in place of private capital inflows, we do not find a statistically significant relationship with our measure of overvaluation, either in the cross section or in the panel. There is a huge endogeneity problem in such regressions, of course, which could explain this in the context of non-industrial countries. Systematic undervaluation could stimulate speculative inflows through unofficial channels when there are selective capital controls in place; similarly, overvaluation may lead to capital flight. (Both these unofficial inflows and outflows would be reflected in the errors and omissions category of the balance of payments.) This is why measures of private capital inflows may be more relevant for understanding the effects of net flows on exchange rates. There is an endogeneity problem in this case as well, but it should drive the correlations that we report in table 6 negative (more overvaluation reduces inflows of private inflows through official channels). Hence the positive correlations that we find are still interesting.

${ }^{62}$ Although this particular specification is sensitive to the inclusion of Mauritius, in others, where the Africa dummy is dropped, the result is more robust.

${ }^{63}$ Alternative lag structures yield a significant coefficient on the overvaluation term.
} 
overvaluation decreases annual growth by about 0.4 percentage point. ${ }^{64}$

Figure 13 conveys some of the flavor of the panel relationship. The figure plots growth and overvaluation over time for countries that experienced growth spurts, ${ }^{65}$ differentiating their performance before and during the growth spurt. On average, overvaluation is substantially less during the growth spurt than before. It is noteworthy that the turnaround in overvaluation is more stark when we exclude, in the bottom panel, the three industrial countries (Ireland, Portugal, and Spain) from the group of sustained growers. This is also consistent with our findings on the differing experiences of industrial and developing countries.

It is also useful to ask whether countries can get as much of a competitive advantage from undervaluation as they will suffer a competitive disadvantage from overvaluation. We estimate separate slopes for countries with overvaluation and for countries with undervaluation (regression 79). The negative effect is twice as large, and statistically significant, in the former. It is also negative for the latter (suggesting that these countries secure a mild competitive advantage), but the coefficient in this case is not significantly different from zero. The true test, though, of whether exchange rate misalignment plays a symmetric role both when positive and when negative is whether the coefficients are different from each other. Here we cannot reject the possibility that they are the same. More work is clearly needed.

EXPORTS AND EXCHANGE RATES: WITHIN-COUNTRY, BETWEEN-INDUSTRY VARIATION. The reduced-form relationship between overvaluation and growth should be mediated through exports and, in particular, manufacturing exports. We now present evidence, based on industry-level data, that suggests that this is indeed the case. As in the previous section, we exploit the within-country, across-industry variation, which allows us to address issues of endogeneity and reverse causality that cannot easily be dealt with even using panel macroeconomic data. The intuition on which these regressions are based is that, in countries with more competitive exchange rates, industries that are "exportable" (that is, whose products have greater inherent export potential) should see faster growth than industries that are less exportable. This intuition is formalized in the following specification:

\footnotetext{
${ }^{64}$ Since the overvaluation term is instrumented in the panel, reverse causation should be less of a concern. See also Razin and Collins (1999).

${ }^{65}$ Again, as identified by Hausmann, Pritchett, and Rodrik (2005).
} 


$$
G_{i j}=\psi+\zeta_{1}{ }^{\prime} C_{j}+\zeta_{2} I_{i}+\zeta_{3} \text { man }_{i j}+\alpha\left(\text { overval }_{j} \times \text { xport }_{i}\right)+\varepsilon_{i j}
$$

where $C_{j}$ is a vector of country indicator variables; $I_{i}$ is a vector of industry indicator variables; man $_{i j}$ is industry $i$ 's initial-period share of manufacturing in country $j$; overval $l_{j}$ is real overvaluation in country $j$; and xport $_{i}$ is the exportability of industry $i$.

The coefficient of interest for us is $\alpha$. It captures an interaction between a country-specific overvaluation variable and an industry's exportability. We posit that countries with greater overvaluation should see a more negative impact in industries that are more exportable, and so we would expect $\alpha$ to be negative.

Before running this regression, we need to measure the inherent exportability of an industry. Since this is clearly a function of a country's endowment and level of income, we are on safer ground in restricting our sample to developing countries, which are likely to be more similar in their potential export trading patterns. However, even within our sample, countries are at varying levels of development. We therefore define exportability in two ways. First, we divide the sample of developing countries into two groups, based on whether their income lies above or below the median. For each group we calculate the ratio of exports to value added for each industry $i$, averaged across all countries in the group. Industries that have ratios above the median within the group we call exportable. Finally, we create an exportable indicator that is equal to 1 for these above-the-median industries; for the other industries the indicator variable takes on a value of zero.

Our second measure of exportability is simpler. We know from the postwar history of world trade that developing countries typically have comparative advantage in the textiles and clothing industry and the leather and footwear industry. So we code the four industries in the U.N. Industrial Development Organization database that fall into these categories as exportable, and we create an indicator variable that takes a value of 1 for these industries and zero otherwise. The difference between this indicator variable and the first is that our textiles and leather indicator is common to all developing countries in the sample, whereas our first indicator can vary across the two groups of developing countries - richer and poorer - in our sample.

Table 8 presents results using the first indicator variable for the 1980s (regression 8-1), the 
1990s (regression 8-4), and the pooled data (regression 8-7). ${ }^{66}$ The coefficient on the interaction between the overvaluation variable and the exportability indicator is negative and significant for both the 1980s and the 1990s. One way to interpret the coefficient is to say that, in a country whose currency is overvalued in real terms by 1 standard deviation (about 24 percentage points) more than that of another country, exportable industries grow 1.4 percentage points $(0.0006 \times 24)$ a year more slowly than other industries in the first country relative to the second. This is substantial when compared with the annual growth rate of the average sector in the sample of about 3.5 percent.

Regressions 8-2, 8-5, and 8-8 are for the same specification but with the textiles, clothing, leather, and footwear industries as the exportable industries. Again the coefficient on the interaction term is negative and significant. It is also greater for these industries than for those in the previous sample, which is reassuring because it suggests that, even within exportable industries, the most obviously exportable ones suffer more in the presence of overvaluation. Finally, we repeat the exercise in regressions 8-3, 8-6, and 8-9, this time restricting the definition of exportable industries to just textiles and clothing, and again we find that the coefficients are significant and increase in magnitude for these clearly exportable sectors.

To summarize, we have presented evidence that capital inflows can result in overvaluation in nonindustrial countries and that overvaluation can hamper overall growth. To bolster this claim, we have shown that overvaluation particularly impinges on the growth of exportable industries. Although the industry-level results go some way toward addressing concerns about endogeneity, the issue remains whether they scale up to the economy as a whole. Again, although these results are not conclusive, since they are, after all, based on reduced-form estimations, the fact that the macroeconomic evidence and the industry-level evidence tell a consistent story provides some comfort that our interpretation is reasonable. The results presented in this section in some ways also generalize the point made by Rajan and Subramanian about the deleterious effects of aid inflows on poor countries' exchange rate competitiveness. ${ }^{67}$

\footnotetext{
${ }^{66}$ It is less easy to run these regressions in a panel context because the exportability index exhibits virtually no time variation, and the overvaluation variable is also quite persistent across the two decades. So there is very little time variation to enable identification.

${ }^{67}$ Rajan and Subramanian (2005).
} 


\section{Conclusion}

Our analysis makes clear that nonindustrial countries that have relied on foreign capital have not grown faster than those that have not. Indeed, taken at face value, there is a growth premium associated with these countries not relying on foreign finance. Equally clearly, though, the reliance of these countries on domestic rather than foreign saving to finance investment comes at a cost: investment and consumption are less than they would be if these countries could draw in foreign capital on the same terms as industrial countries' or on the same terms as they can use their own domestic capital.

It does not seem to us that these nonindustrial countries are building up foreign assets just to serve as collateral, which can then draw in beneficial forms of foreign financing such as FDI. ${ }^{68}$ Rather, it seems to us that even successful developing countries have limited absorptive capacity for foreign resources, whether because their financial markets are underdeveloped, or because their economies are prone to overvaluation caused by rapid capital inflows or overly rapid consumption growth, or some combination of these factors.

As countries develop, absorptive capacity grows. The recent strong growth of the emerging economies of Europe, accompanied by rising current account deficits, probably has a lot to do with the strengthening of their financial sectors, in part through the entry of foreign banks. Only time will tell what effects there are on the exchange rate and on competitiveness, as well as whether this phenomenon is sustainable, and so all conclusions from this episode have to be tentative. ${ }^{69}$

In sum, our results suggest that insofar as the need to avoid overvaluation is important and the domestic financial sector is underdeveloped, greater caution toward certain forms of foreign capital inflows might be warranted. At the same time, however, financial openness may be needed to spur domestic financial development. ${ }^{70}$ This suggests that even though reformers in developing countries might want to wait to achieve a certain level of financial development before pushing for financial integration, the prospect of financial integration and ensuing

\footnotetext{
${ }^{68}$ See, for example, Dooley, Folkerts-Landau, and Garber (2004a, 2004b). Why, for example, would Korea or Taiwan be comforted, when making direct investments in China, by the fact that China holds enormous amounts of U.S. government securities?

${ }^{69}$ Of course, if development helps countries absorb foreign capital better, why is the correlation between current account balances and growth for nonindustrial countries getting stronger over time, as figure 5 suggests? This is an important question for future research.

${ }^{70}$ See, for example, Rajan and Zingales (2003), Mishkin (2006), and Kose and others (2006).
} 
competition may be needed to spur domestic financial development. One approach worth considering might be a firm commitment to integrate financial markets at a definite future date; this would allow time for the domestic financial system to develop without possible adverse effects from capital inflows, even while giving participants the incentive to press for it by suspending the sword of future foreign competition over their heads. ${ }^{71}$

A bleak read of the message in this paper is that because development itself may be the antidote to the deleterious effects of foreign capital and may be necessary for countries to absorb more capital, only some forms of foreign capital may play a direct role in the development process. Certainly, the role of foreign capital in expanding a country's resource constraints may be limited. A more optimistic read would see a research and, eventually, policy agenda in determining how to increase the capacity of poor countries to absorb foreign capital.

Over time, and especially in the aftermath of the East Asian crisis of the late 1990s, certitudes about financial integration have gradually yielded to greater circumspection-a trend that this paper suggests was perhaps warranted. But what does all this mean for policies toward capital account openness? Certainly, the answer is not to go backward, but instead toward more country and context specificity in assessing the merits of capital account openness, and more flexibility and creativity in managing it. ${ }^{72}$ Even in his avatar that was skeptical of financial integration, Keynes said, "Yet, at the same time, those who seek to disembarrass a country of its entanglements should be very slow and wary. It should not be a matter of tearing up roots but of slowly training a plant to grow in a different direction."

\footnotetext{
${ }^{71}$ The Chinese approach of trying to spur banking reform by committing to open up the country's banking sector to foreign competition in early 2007, as part of their World Trade Organization accession commitments, can be seen in this light. Prasad and Rajan (2005) suggest an alternative strategy for dealing with the potential adverse effects of inflows through controlled liberalization of outflows (essentially by securitizing inflows), which would allow countries experiencing large capital inflows to develop their domestic financial markets and simultaneously mitigate appreciation pressures associated with those inflows.

${ }^{72}$ For instance, capital account openness means more than just opening up to inward flows; it also means allowing outward flows. Outward flows could well relieve incipient appreciation pressures on the national currency, but they could also be a source of fragility, especially if the financial sector is underdeveloped. The fragility associated with the exit of capital could be attenuated if an economy is more open to trade (see Calvo, Izquierdo, and Mejia, 2004, and Frankel and Cavallo, 2004); trade openness could also mitigate the adverse effects of crises.
} 


\section{References}

Abiad, Abdul, Daniel Leigh, and Ashoka Mody. 2007. "International Finance and Income Convergence: Europe is Different." Working Paper 07/64. Washington: International Monetary Fund (March).

Aghion, Philippe, Diego Comin, and Peter Howitt. 2006. "When Does Domestic Saving Matter for Economic Growth?" Working Paper 12275. Cambridge, Mass.: National Bureau of Economic Research (June).

Aizenman, Joshua, Brian Pinto, and Artur Radziwill. 2004. "Sources for Financing Domestic Capital-Is Foreign Saving a Viable Option for Developing Countries?" Working Paper 10624. Cambridge, Mass.: National Bureau of Economic Research (July).

Alfaro, Laura, and Eliza Hammel. 2007. "Capital Flows and Capital Goods." Journal of International Economics 72, no. 1: 128-50.

Alfaro, Laura, Sebnem Kalemli-Ozcan, and Vadym Volosovych. 2005. "Why Doesn't Capital Flow from Rich to Poor Countries? An Empirical Investigation." Working Paper 11901. Cambridge, Mass.: National Bureau of Economic Research (December).

Arellano, Manuel, and Stephen Bond. 1991. "Some Tests of Specification for Panel Data: Monte Carlo Evidence and an Application to Employment Equations." Review of Economic Studies 58, no. 2: 277-97.

Bekaert, Geert, Campbell R. Harvey, and Christian Lundblad. 2005. "Does Financial Liberalization Spur Growth?” Journal of Financial Economics 77, no. 1: 3-55.

Bernanke, Ben S. 2005. "The Global Saving Glut and the U.S. Current Account Deficit." Remarks at the Sandridge Lecture, Virginia Association of Economics, Richmond, Va., March 10

(www.federalreserve.gov/boarddocs/speeches/2005/200503102/default.htm).

. 2006. “Global Economic Integration: What's New and What's Not?" Remarks at the Federal Reserve Bank of Kansas City's Thirtieth Annual Economic Symposium, Jackson Hole, Wyo., August 25

(www.federalreserve.gov/boarddocs/speeches/2006/20060825/default.htm).

Bernanke, Ben S., and Refet S. Gürkaynak. 2002. "Is Growth Exogenous? Taking Mankiw, Romer, and Weil Seriously." NBER Macroeconomics Annual 2001, edited by Ben S. Bernanke and Kenneth S. Rogoff. MIT Press.

Blundell, Richard, and Stephen Bond. 1998. "Initial Conditions and Moment Restrictions in Dynamic Panel Data Models.” Journal of Econometrics 87, no. 1: 115-43.

Borensztein, Eduardo, José De Gregorio, and Jong-Wha Lee. 1998. "How Does Foreign Direct Investment Affect Economic Growth?" Journal of International Economics 45, no. 1: 115-35.

Bosworth, Barry P., and Susan M. Collins. 1999. "Capital Flows to Developing Countries: Implications for Saving and Investment." BPEA, no. 1: 143-69.

. 2003. "The Empirics of Growth: An Update.” BPEA, no. 2: 113-79.

Caballero, Ricardo J., Emmanuel Farhi, and Pierre-Olivier Gourinchas. 2006. "An Equilibrium Model of 'Global Imbalances' and Low Interest Rates." Working Paper 11996. Cambridge, Mass.: National Bureau of Economic Research (February).

Calvo, Guillermo, Alejandro Izquierdo, and Luis-Fernando Mejía. 2004. "On the Empirics of 
Sudden Stops: The Relevance of Balance-Sheet Effects." Paper presented at a Federal Reserve Bank of San Francisco Conference on Emerging Markets and Macroeconomic Volatility: Lessons from a Decade of Financial Debacles, San Francisco, June 4.

Carroll, Christopher D., and David N. Weil. 1994. "Saving and Growth: A Reinterpretation." Carnegie-Rochester Conference Series on Public Policy 40: 133-92.

Caselli, Francesco, and James Feyrer. 2007. "The Marginal Product of Capital.” Quarterly Journal of Economics 122, no. 2: 535-68.

Chinn, Menzie D., and Hiro Ito. 2006. "What Matters for Financial Development? Capital Controls, Institutions, and Interactions." Journal of Development Economics 81, no. 1: 163-92.

Chinn, Menzie D., and Eswar S. Prasad. 2003. "Medium-Term Determinants of Current Accounts in Industrial and Developing Countries: An Empirical Exploration." Journal of International Economics 59, no. 1: 47-76.

De Nicolò, Gianni, Luc Laeven, and Kenichi Ueda. 2006. “Corporate Governance Quality in Asia: Comparative Trends and Impact.” International Monetary Fund.

Detragiache, Enrica, Thierry Tressel, and Poonam Gupta. 2006. "Foreign Banks in Poor Countries: Theory and Evidence." IMF Working Paper 06/18. Washington: International Monetary Fund (January).

Dooley, Michael P., David Folkerts-Landau, and Peter M. Garber. 2004a. "The Revived Bretton Woods System: The Effects of Periphery Intervention and Reserve Management on Interest Rates and Exchange Rates in Center Countries." Working Paper 10332. Cambridge, Mass.: National Bureau of Economic Research (March).

. 2004b. "The U.S. Current Account Deficit and Economic Development: Collateral for a Total Return Swap." Working Paper 10727. Cambridge, Mass.: National Bureau of Economic Research (September).

Edwards, Sebastian. 2005. "Capital Controls, Sudden Stops, and Current Account Reversals." Working Paper 11170. Cambridge, Mass.: National Bureau of Economic Research (March).

Frankel, Jeffrey A., and Eduardo A. Cavallo. 2004. "Does Openness to Trade Make Countries More Vulnerable to Sudden Stops, or Less? Using Gravity to Establish Causality." Working Paper 10957. Cambridge, Mass.: National Bureau of Economic Research (December).

Gertler, Mark, and Kenneth S. Rogoff. 1990. "North-South Lending and Endogenous Domestic Capital Market Inefficiencies.” Journal of Monetary Economics 26, no. 2: 245-66.

Glick, Reuven, and Kenneth S. Rogoff. 1995. "Global Versus Country-Specific Productivity Shocks and the Current Account." Journal of Monetary Economics 35, no. 1: 159-92.

Glick, Reuven, Xueyan Guo, and Michael Hutchison. 2006. "Currency Crises, Capital Account Liberalization, and Selection Bias." Review of Economics and Statistics 88, no 4: 698-714.

Gourinchas, Pierre-Olivier, and Olivier Jeanne. 2006a. "Capital Flows to Developing Countries: The Allocation Puzzle." University of California, Berkeley, and International Monetary Fund.

. 2006b. "The Elusive Gains from International Financial Integration." Review of Economic Studies 73, no. 3: 715-41.

Hall, Robert E., and Charles I. Jones. 1999. "Why Do Some Countries Produce So Much More Output per Worker Than Others?" Quarterly Journal of Economics 114, no. 1: 83-116. 
Hausmann, Ricardo, Lant Pritchett, and Dani Rodrik. 2005. "Growth Accelerations." Journal of Economic Growth 10, no. 4: 303-29.

Henry, Peter Blair. 2006. "Capital Account Liberalization: Theory, Evidence, and Speculation." Working Paper 12698. Cambridge, Mass.: National Bureau of Economic Research (November).

Henry, Peter Blair, and Prakash Kannan. 2007. "Growth and Returns in Emerging Markets." In International Financial Issues in the Pacific Rim: Global Imbalances, Financial Liberalization, and Economics, vol. 17. University of Chicago Press.

Exchange Rate Policy. East Asia Seminar on

Houthakker, Hendrik S. 1961. “An International Comparison of Personal Savings.” Bulletin of the International Statistical Institute 38: 55-69.

Hsieh, Chang-Tai, and Peter J. Klenow. 2003. "Relative Prices and Relative Prosperity." Working Paper 9701. Cambridge, Mass.: National Bureau of Economic Research (May).

Jappelli, Tullio, and Marco Pagano. 1994. "Saving, Growth, and Liquidity Constraints." Quarterly Journal of Economics 109, no. 1: 83-109.

Johnson, Simon, Jonathan D. Ostry, and Arvind Subramanian. 2007. "The Prospects for Sustained Growth in Africa: Benchmarking the Constraints." Working Paper 07/52. Washington: International Monetary Fund (March).

Jones, Benjamin F., and Benjamin A. Olken. 2005. "The Anatomy of Start-Stop Growth." Working Paper 11528. Cambridge, Mass.: National Bureau of Economic Research (August).

Keynes, John Maynard. 1920. The Economic Consequences of the Peace. New York: Harcourt, Brace, and Howe. . 1933. "National Self-Sufficiency.” Yale Review 22, no. 4: 755-69.

Kose, M. Ayhan, Eswar S. Prasad, and Marco E. Terrones. 2006. "How Do Trade and Financial Integration Affect the Relationship between Growth and Volatility?" Journal of International Economics 69, no. 1: 176-202.

Kose, M. Ayhan, and others. 2006. "Financial Globalization: A Reappraisal.” Working Paper 06/189. Washington: International Monetary Fund (August).

Kraay, Aart, and Jaume Ventura. 2000. "Current Accounts in Debtor and Creditor Countries." Quarterly Journal of Economics 115, no. 4: 1137-66.

Lane, Philip R., and Gian Maria Milesi-Ferretti. 2002. "Long-Term Capital Movements.” NBER Macroeconomics Annual 2001, edited by Ben S. Bernanke and Kenneth S. Rogoff. MIT Press.

. 2006. "The External Wealth of Nations Mark II: Revised and Extended Estimates of Foreign Assets and Liabilities, 1970-2004." Working Paper 06/69. Washington: International Monetary Fund (March).

Lucas, Robert E., Jr. 1990. "Why Doesn't Capital Flow from Rich to Poor Countries?" American Economic Review 80, no. 2: 92-96.

Meese, Richard A., and Kenneth Rogoff. 1983. "Empirical Exchange Rate Models of the Seventies: Do They Fit Out of Sample?" Journal of International Economics 14, nos. 1-2: 3-24.

Mishkin, Frederic S. 2006. The Next Great Globalization: How Disadvantaged Nations Can Harness Their Financial Systems to Get Rich. Princeton University Press.

Modigliani, Franco. 1970. "The Life Cycle Hypothesis of Saving and Inter-Country 
Differences in the Saving Ratio." In Induction, Growth and Trade: Essays in Honor of Sir Roy Harro d, edited by Walter A. Eltis, Maurice FitzGerald Scott, and James N. Wolfe. Clarendon Press.

Naranjo, Martin, and Emilio Osambela. 2004. "From Financial Crisis to Correction." In Revitalizing the Jamaican Economy: Policies for Sustained Growth, edited by Desmond Thomas. Washington: Inter-American Development Bank.

Obstfeld, Maurice, and Alan M. Taylor. 2004. Global Capital Markets: Integration, Crisis, and Growth. Cambridge University Press.

Prasad, Eswar S., and Raghuram G. Rajan. 2005. "Controlled Capital Account Liberalization: A Proposal." Policy Discussion Paper 05/7. Washington: International Monetary Fund (October).

Prasad, Eswar, and others. 2006. "Financial Globalization, Growth, and Volatility in Developing Countries." In Globalization and Poverty, edited by Ann Harrison. University of Chicago Press.

Rajan, Raghuram G., and Arvind Subramanian. 2005. "What Undermines Aid's Impact on Growth?" Working Paper 11657. Cambridge, Mass.: National Bureau of Economic Research (October).

Rajan, Raghuram G., and Luigi Zingales. 1998. "Financial Dependence and Growth." American Economic Review 88, no. 3: 559-86.

. 2003. "The Great Reversals: The Politics of Financial Development in the 20th Century." Journal of Financial Economics 69, no. 1: 5-50.

Razin, Ofair, and Susan Collins. 1999. "Real-Exchange-Rate Misalignments and Growth." In The Economics of Globalization: Policy Perspectives from Public Economics, edited by Assaf Razin and Efraim Sadka. Cambridge University Press.

Reinhart, Carmen M., and Kenneth S. Rogoff. 2004. "Serial Default and the 'Paradox' of Rich-toPoor Capital Flows." American Economic Review 94, no. 2: 53-58.

Rodrik, Dani. 2006. "Capital Account Liberalization and Growth: Making Sense of the Stylized Facts." Remarks at the IMF Center Economic Forum: How Does Capital Account Liberalization Affect Economic Growth? Washington, November 10

(www.imf.org/external/np/tr/2006/tr061110.htm\#rod).

. 2007a. "Why Does the Real Exchange Rate Matter to Growth?" Razin Lecture, Georgetown University, March 21.

Harvard University (July)

2007b. "The Real Exchange Rate and Economic Growth: Theory and Evidence." (ksghome.harvard.edu/ drodrik/RER \%20and\%20growth.pdf).

Sachs, Jeffrey D., and Andrew Warner. 1995. "Economic Reform and the Process of Global Integration." BPEA, no. 1: 1-95.

Tressel, Thierry, and Thierry Verdier. 2007. "Financial Globalization and the Governance of Domestic Financial Intermediaries." Working Paper 07/47. Washington: International Monetary Fund (March).

Wurgler, Jeffrey. 2000. "Financial Markets and the Allocation of Capital." Journal of Financial Economics 58, no. 1-2: 187-214. 
Figure 1. World Aggregate Current Account Surplus, 1970-2006 ${ }^{\mathrm{a}}$

\section{Percent of world GDP}

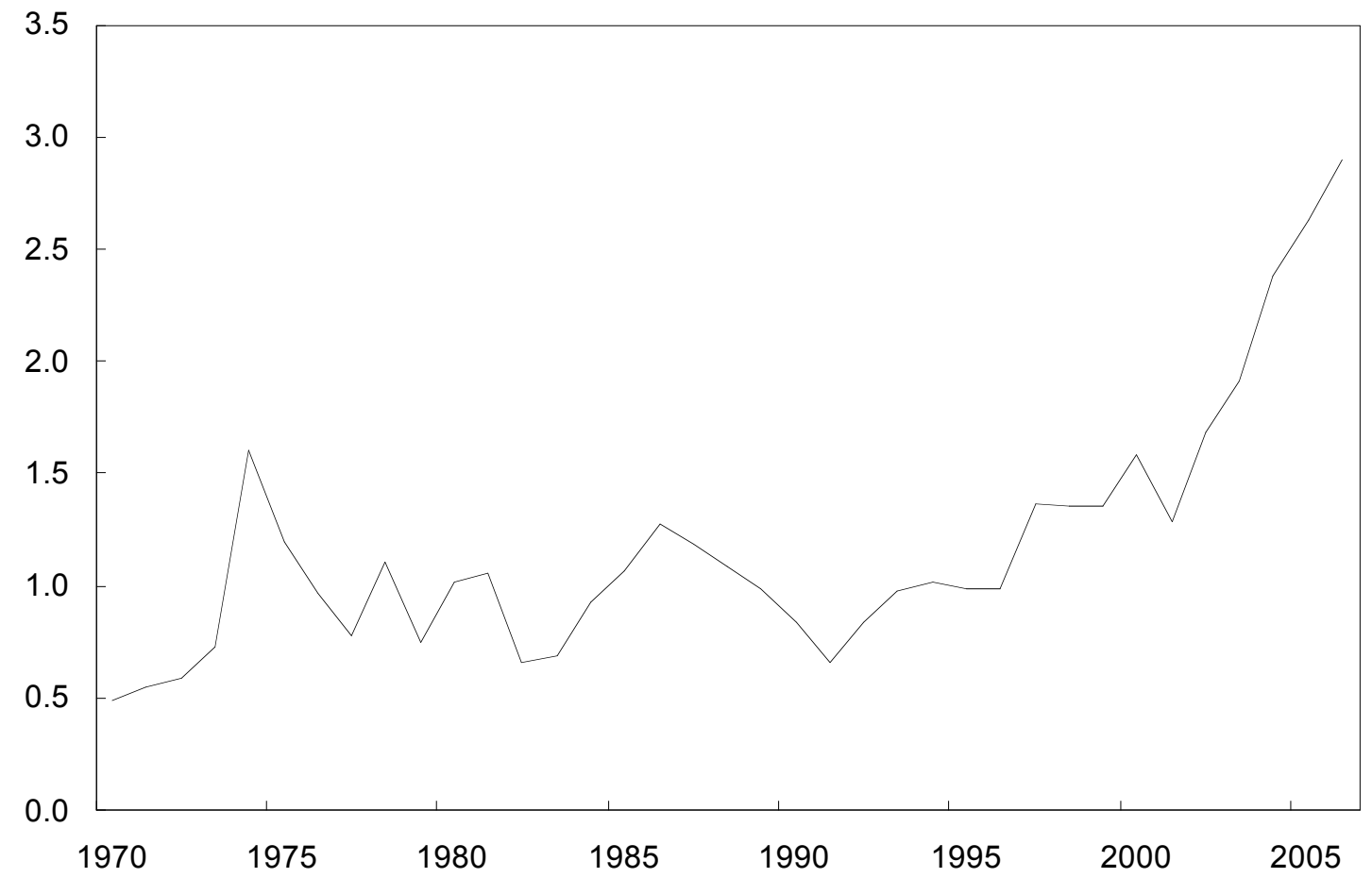

Source: IMF World Economic Outlook (WEO) database and authors' calculations.

a. Each observation is the sum of current account surpluses of countries in the WEO database that had a surplus in that year, as a percent of world GDP as calculated by the IMF. 
Figure 2. Relative GDP per Capita of Capital Exporters and Capital Importers, 1970-2005

Percent of highest GDP per capita in indicated year

\section{All countries}

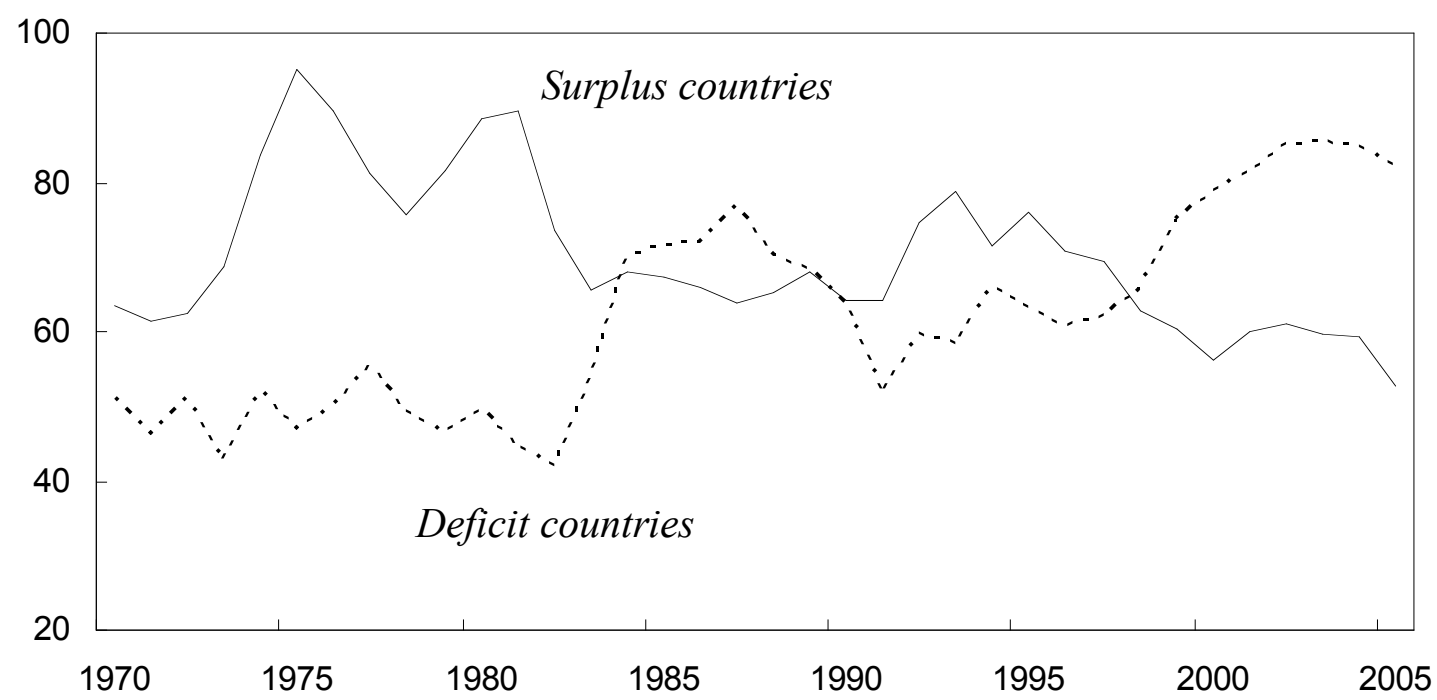

\section{Excluding China and United States}

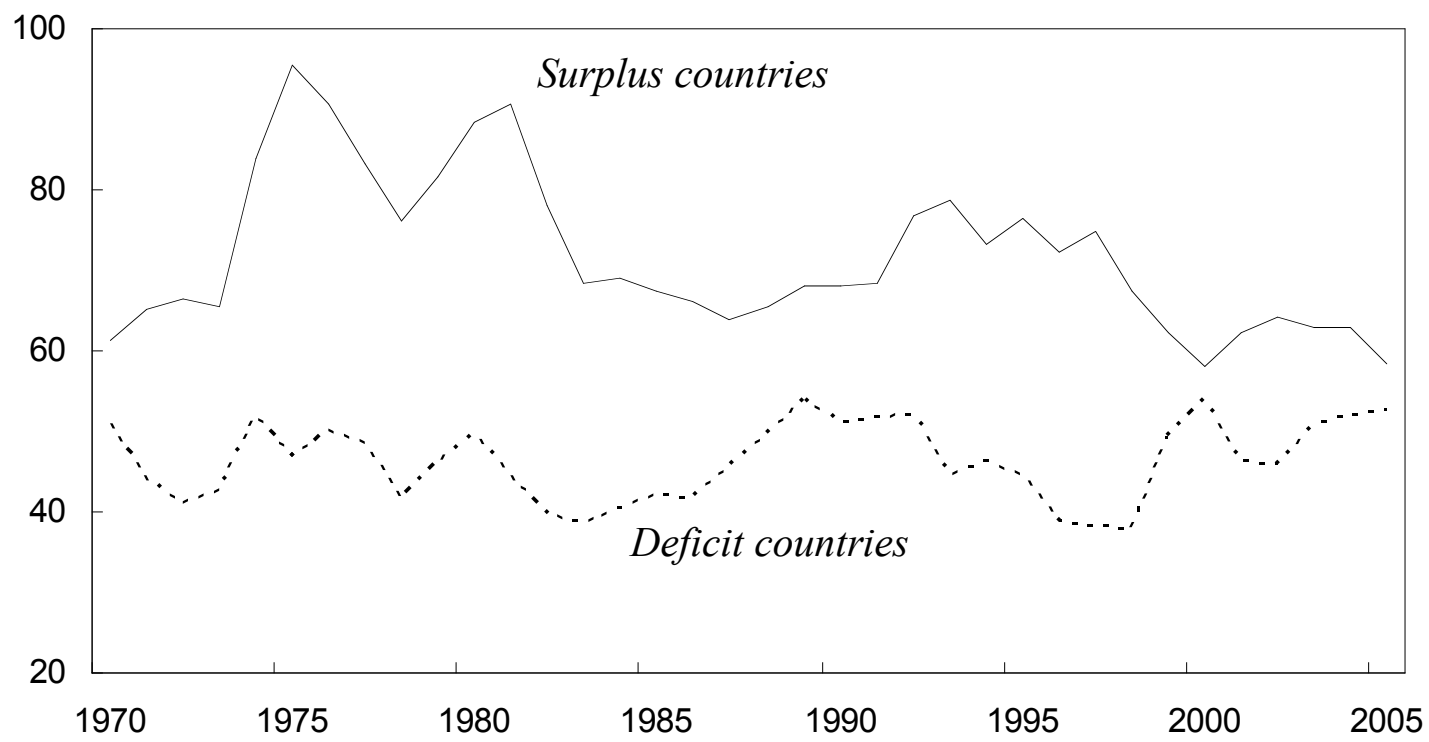

Source: Authors' calculations using data from the WEO database.

a. Each observation is the average GDP per capita (weighted by the country's share of the total current surplus or deficit) of countries in the WEO database with current account surpluses or deficits in the indicated year, expressed as a percentage of GDP per capita in the country with the highest GDP per capita that year. GDP per capita is adjusted for purchasing power parity. 
Figure 3. Cumulative Current Account Deficits and FDI Inflows of Nonindustrial Countries, 1970-2004

Billions of 2004 dollars ${ }^{b}$

\section{Current account deficits}

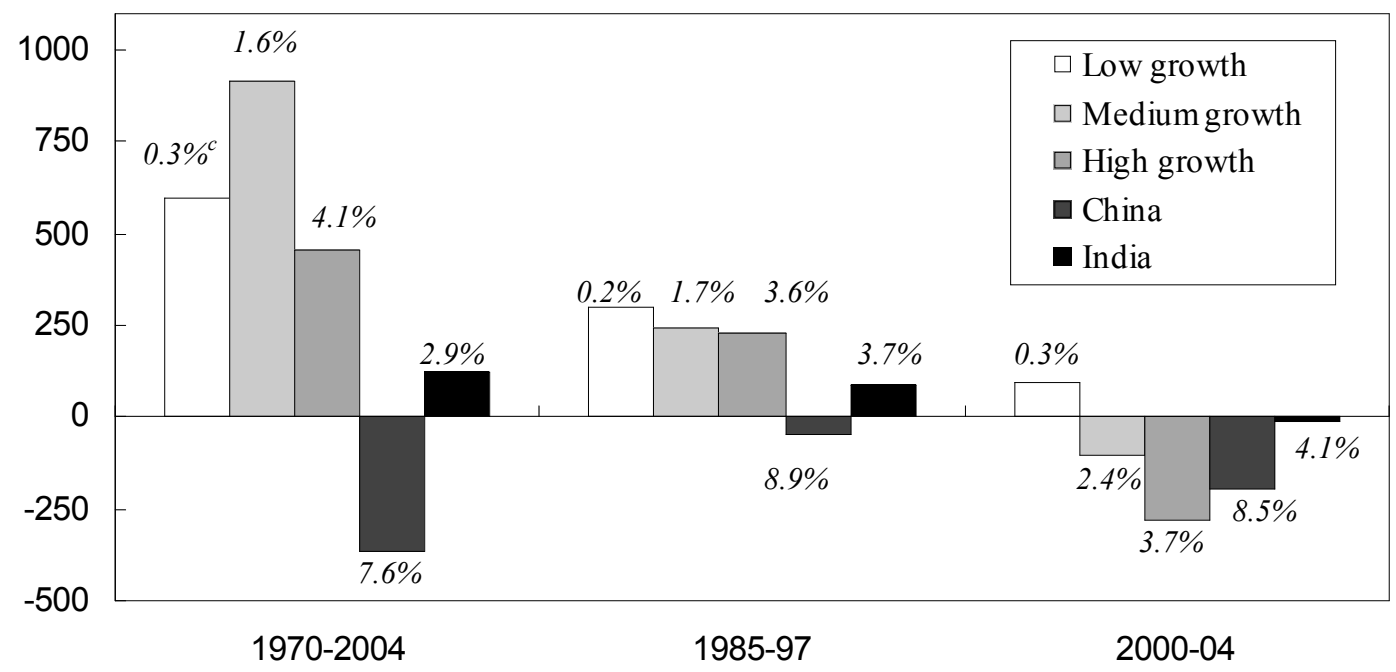

Net FDI inflows

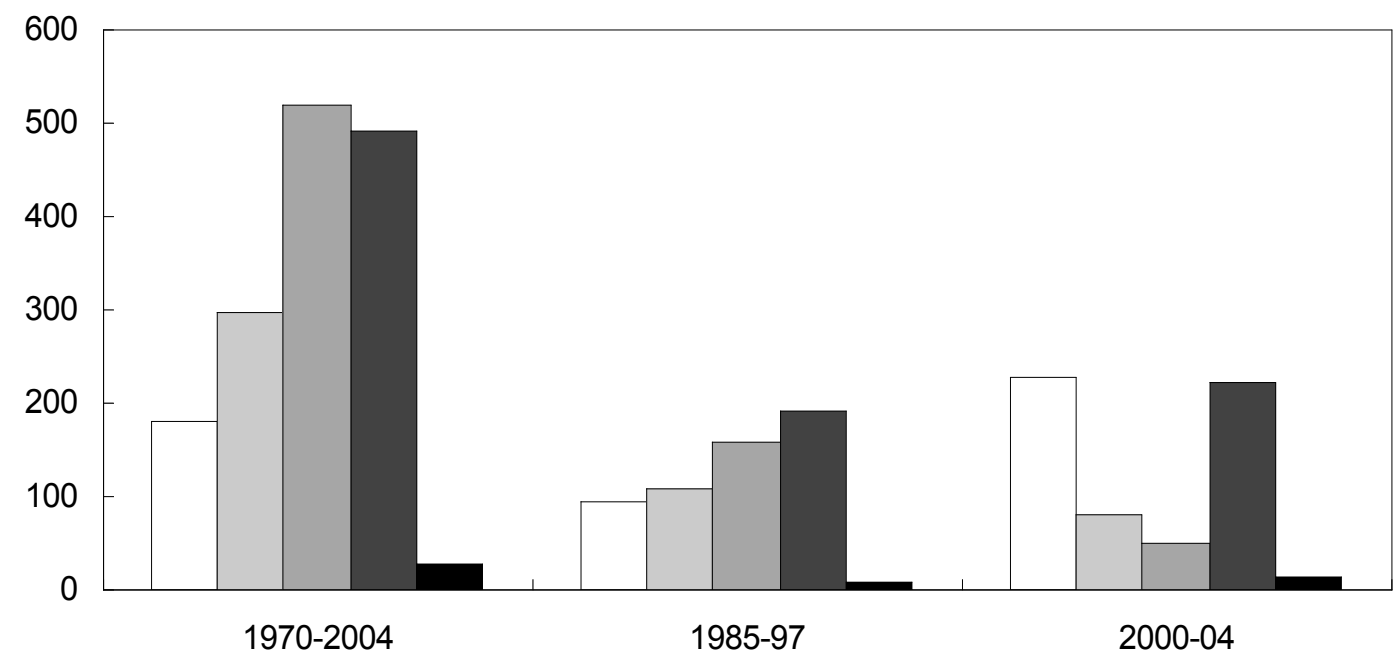

Source: Authors' calculations using data from Penn World Tables (Version 6.2) and Lane and Milesi-Ferretti (2006). a. Our sample of fifty-nine nonindustrial countries, excluding China and India, is divided into three groups of roughly equal total populations based on income per capita. Bar heights indicate the sum of each group's cumulative current account deficit or FDI inflows in the indicated period. Negative numbers in the top panel indicate current account surpluses.

b. Deflated using the U.S. consumer price index.

c. Percentages above each bar indicate the period-average median growth rate of real GDP per capita for that group. 
Figure 4. Growth in GDP per Capita and Level of Current Account Balances, 1970-2004 Growth in GDP per capita (percent a year)

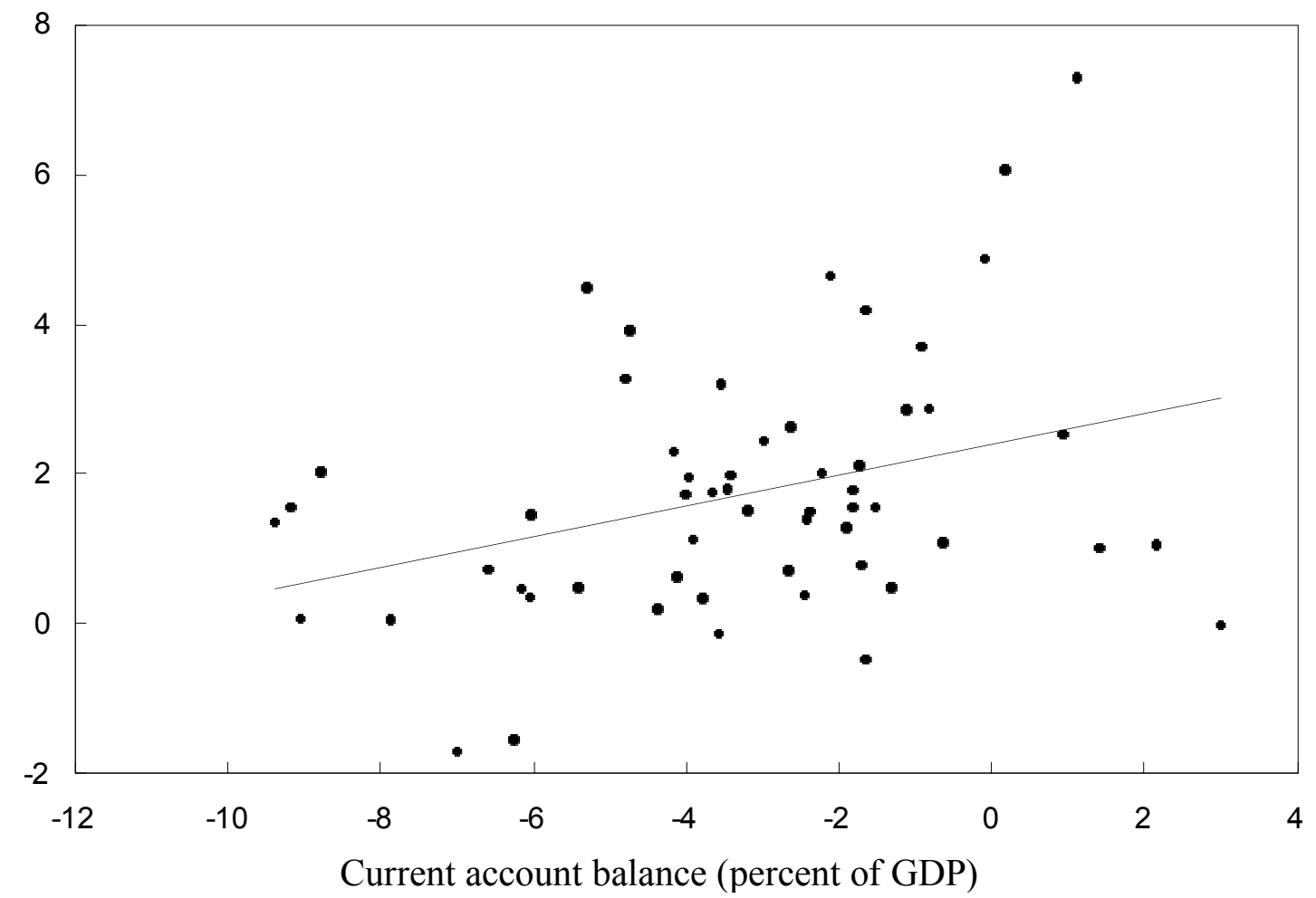

Source: Authors' calculations using data from the Penn World Tables and the World Bank, World Development Indicators.

a. Data are for the fifty-six nonindustrial countries in the core sample (the nonindustrial countries listed in appendix table A-1, excluding outlier Mozambique, Nicaragua, and Singapore). 
Figure 5. GDP Growth and the Current Account Balance over Time: Nonparametric Relationship ${ }^{\text {a }}$

\section{Growth in GDP per capita}

(percent a year)

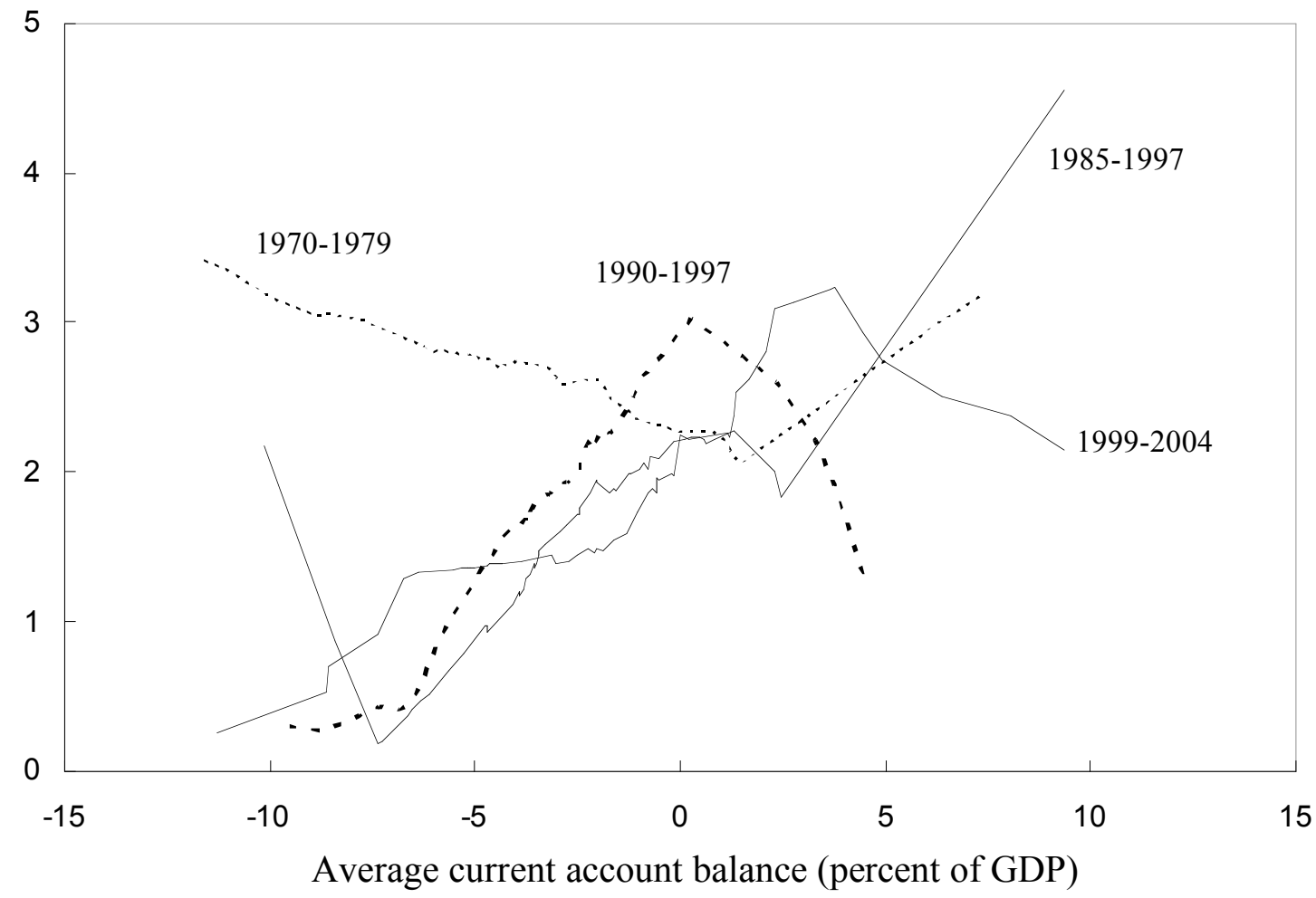

Source: Authors' regressions using data from the Penn World Tables and the World Bank, World Development Indicators. a. Graph plots predicted growth in GDP per capita growth against the current account balance using estimates from locally weighted regressions for each sub-period. Data are for the entire sample of fifty-nine nonindustrial countries plus Bangladesh. 
Figure 6. Growth in GDP per Capita and Levels of Investment and the Current Account, 1970-2004

Growth in GDP per capita

(percent a year)

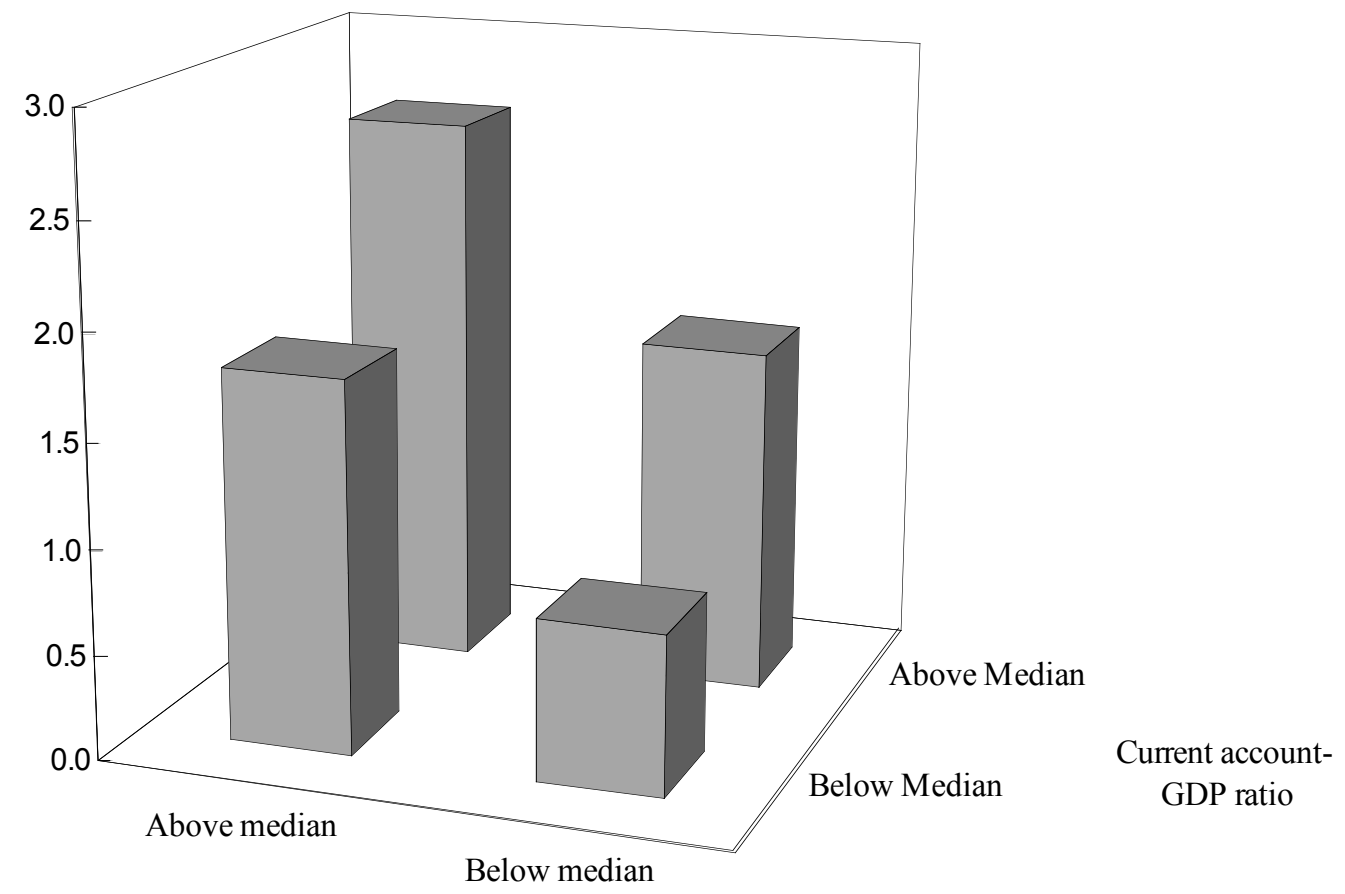

Investment-GDP ratio

Source: Authors' calculations using data from the World Bank, World Development Indicators.

a. Data are for the fifty-nine nonindustrial countries in the entire sample plus Bangladesh. All data are period averages. 
Figure 7. Saving, Investment, and Economic Growth in an Undistorted Economy

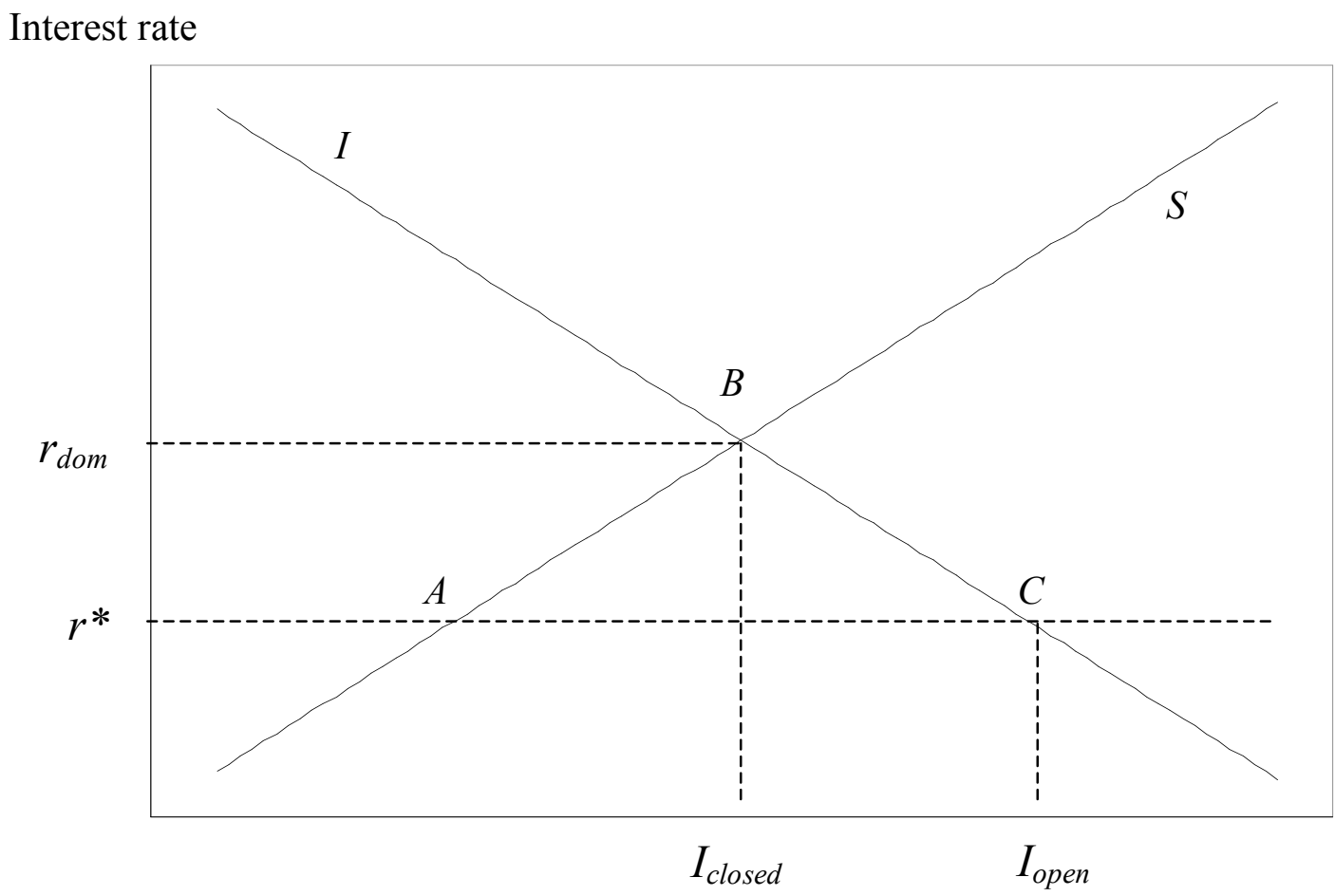

Investment, Saving

Source: Authors' model described in the text. 
Figure 8. Current Account Balance, Saving, and Investment before and after Growth Spurts in Eleven Countries ${ }^{\mathrm{a}}$

\section{Current account balance}

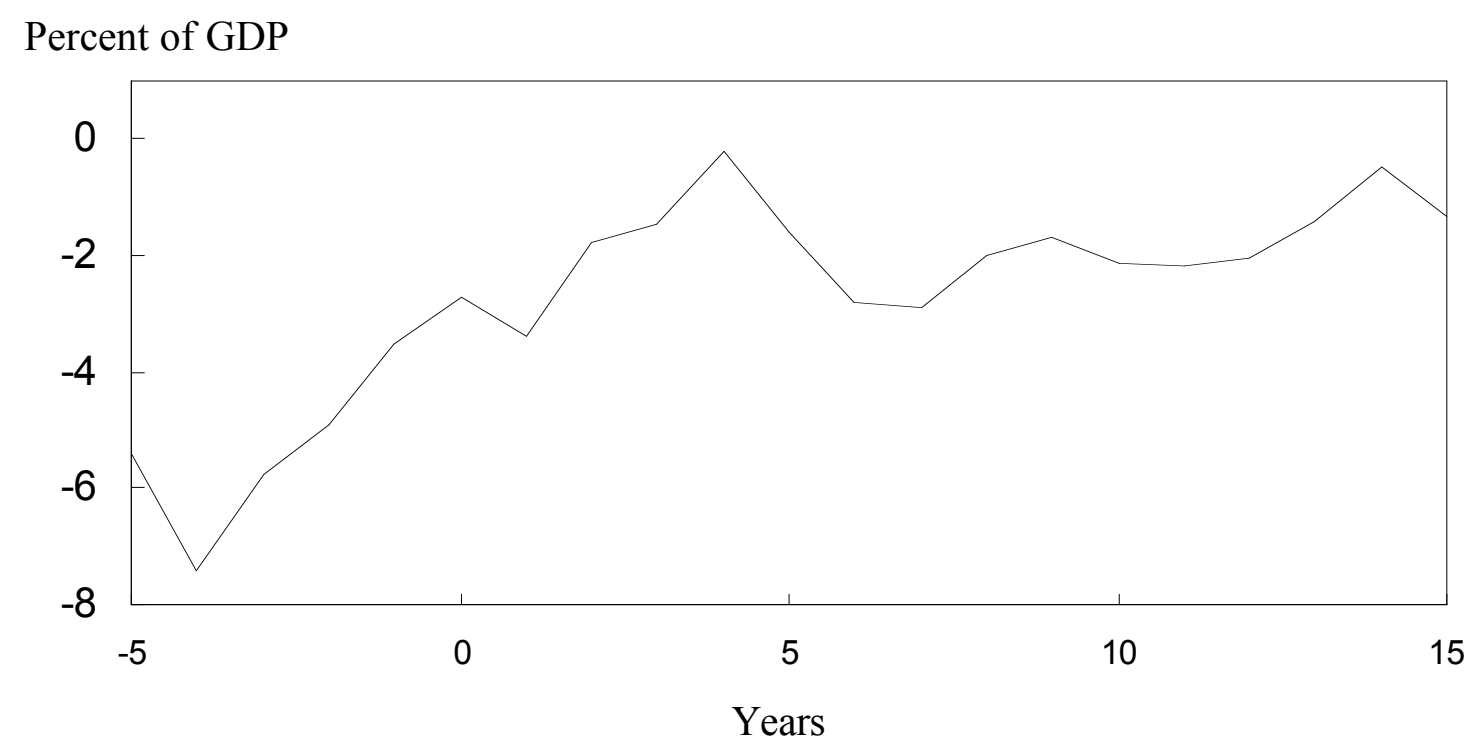

\section{Saving and investment}

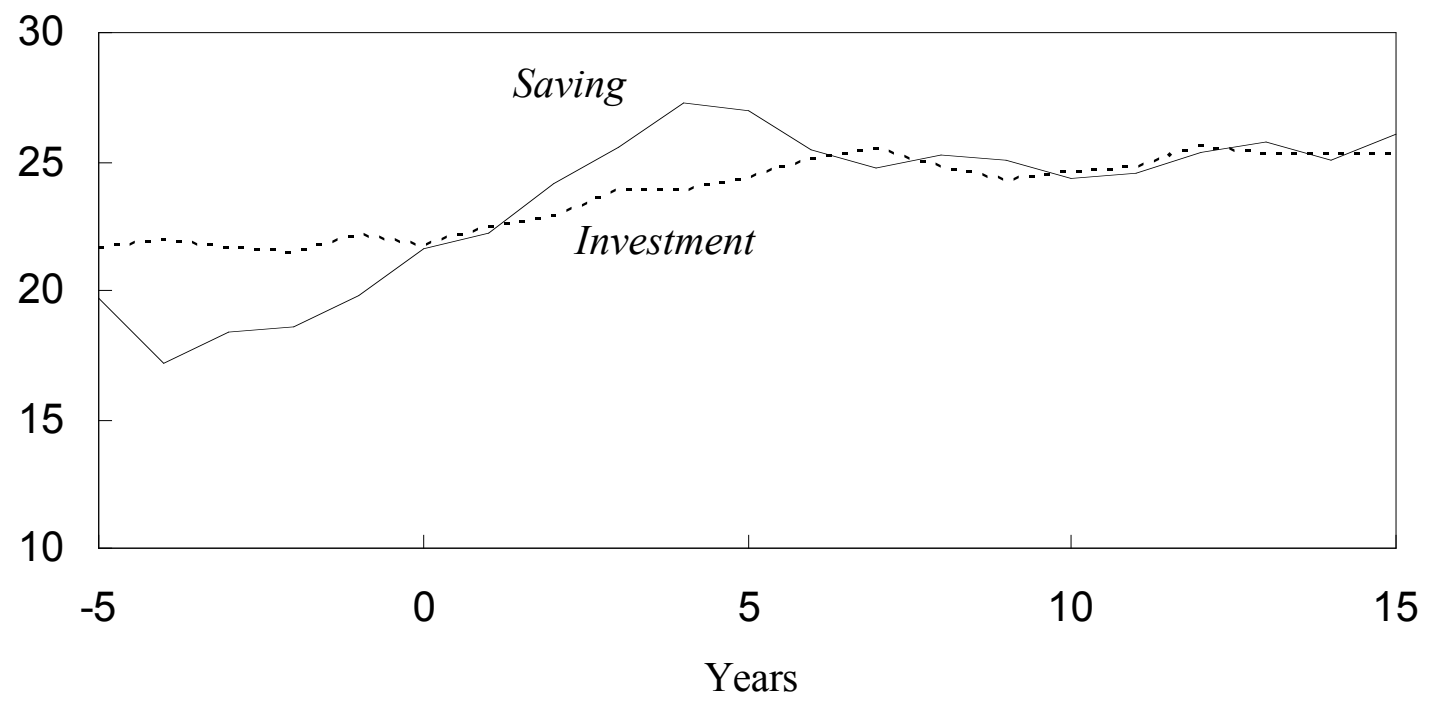

Sources: World Bank, World Development Indicators; the Penn World Tables; Hausmann, Rodrik, and Pritchett (2005); and authors' calculations.

a. Simple averages of current account balance, saving, and investment. Countries and initial year (year 0) of their growth spurts are Chile (1986), China (1978), Egypt (1976), India (1982), Ireland (1985), Korea (1984), Mauritius (1983), Pakistan (1985), Spain (1984), and Sri Lanka (1979). 
Figure 9. Current Account Balance, Saving, and Investment before and after Growth Spurts in Eight Nonindustrial Countries ${ }^{\mathrm{a}}$

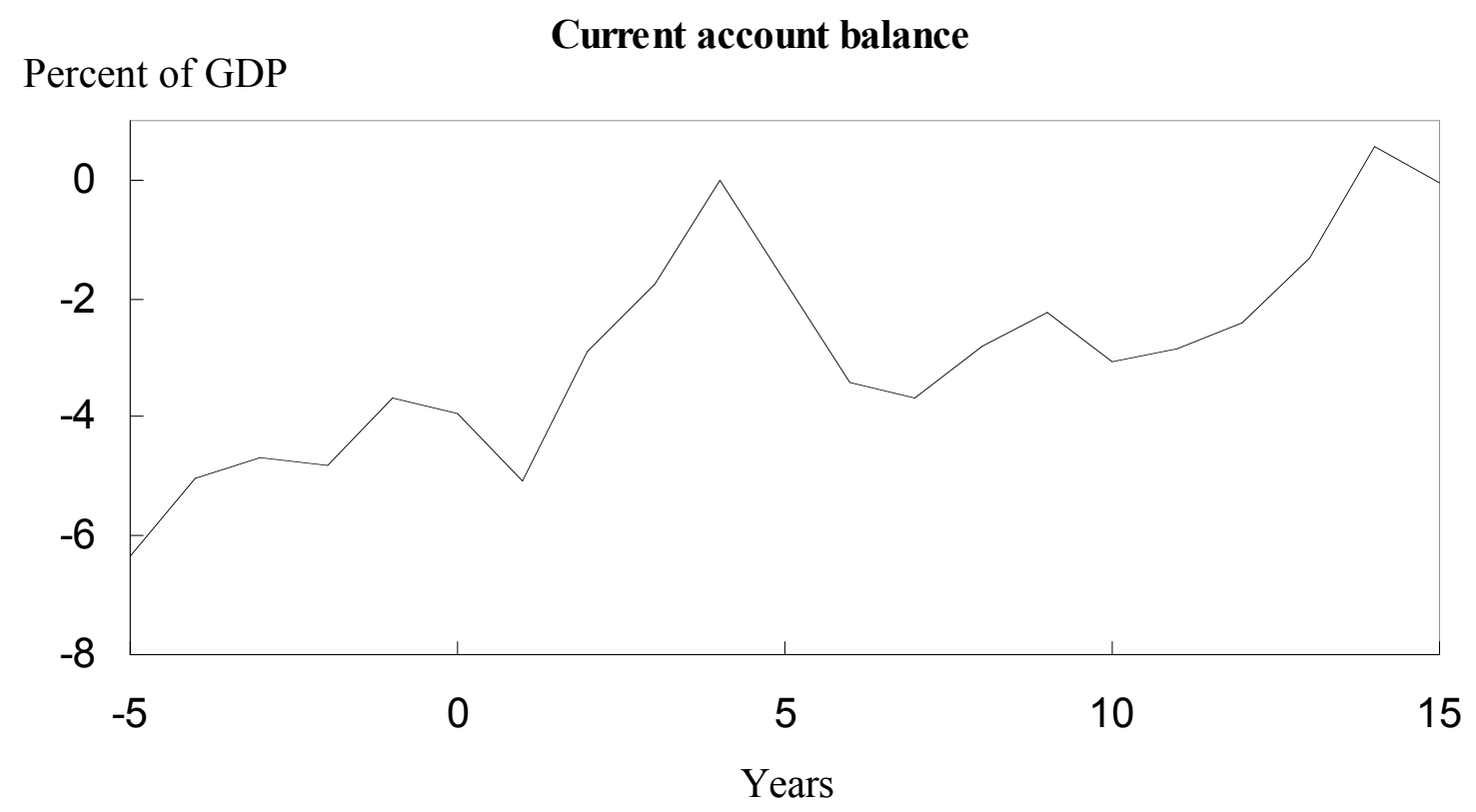

\section{Saving and investment}

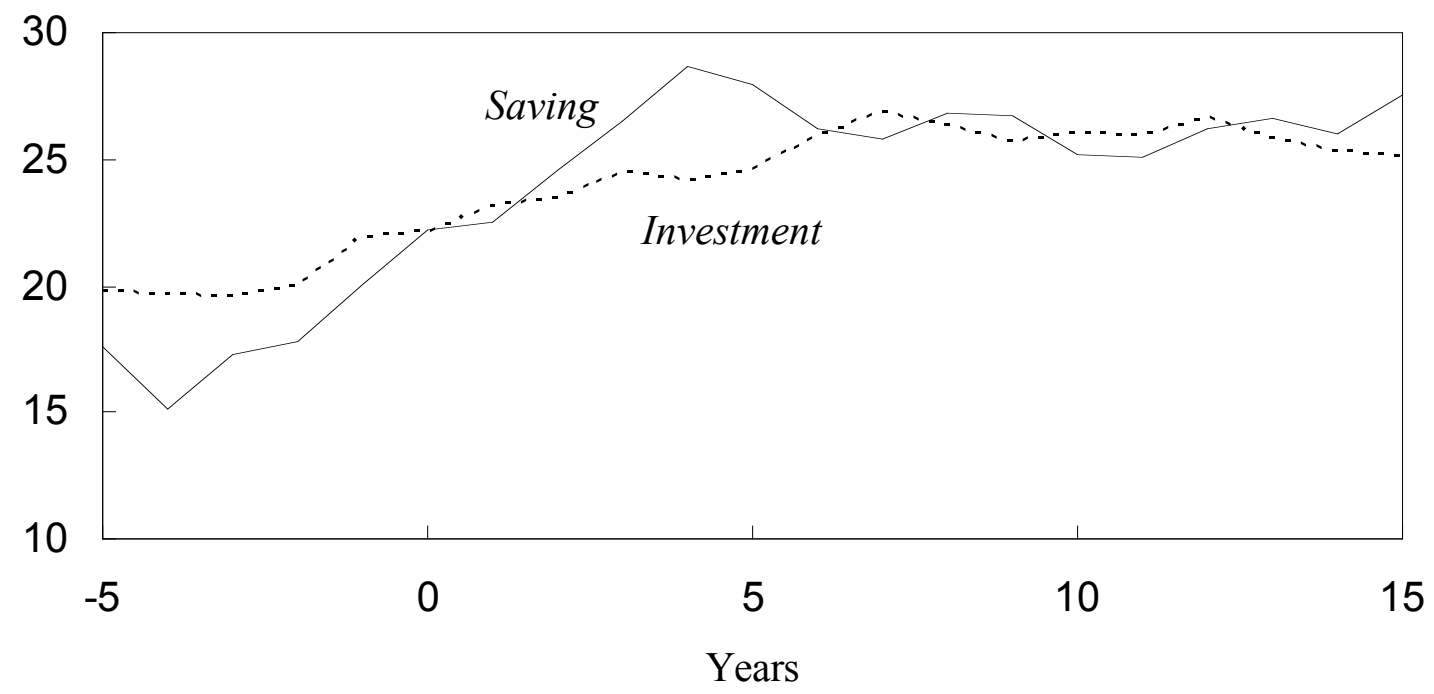

Sources: World Bank, World Development Indicators; the Penn World Tables; Hausmann, Rodrik, and Pritchett (2005); and authors' calculations.

a. Simple averages of current account balance, saving, and investment. Country sample is the same as in figure 8 except that Ireland, Portugal, and Spain are excluded. 
Figure 10. Saving and Investment in an Economy Distorted by Foreign Capital Inflows Interest rate

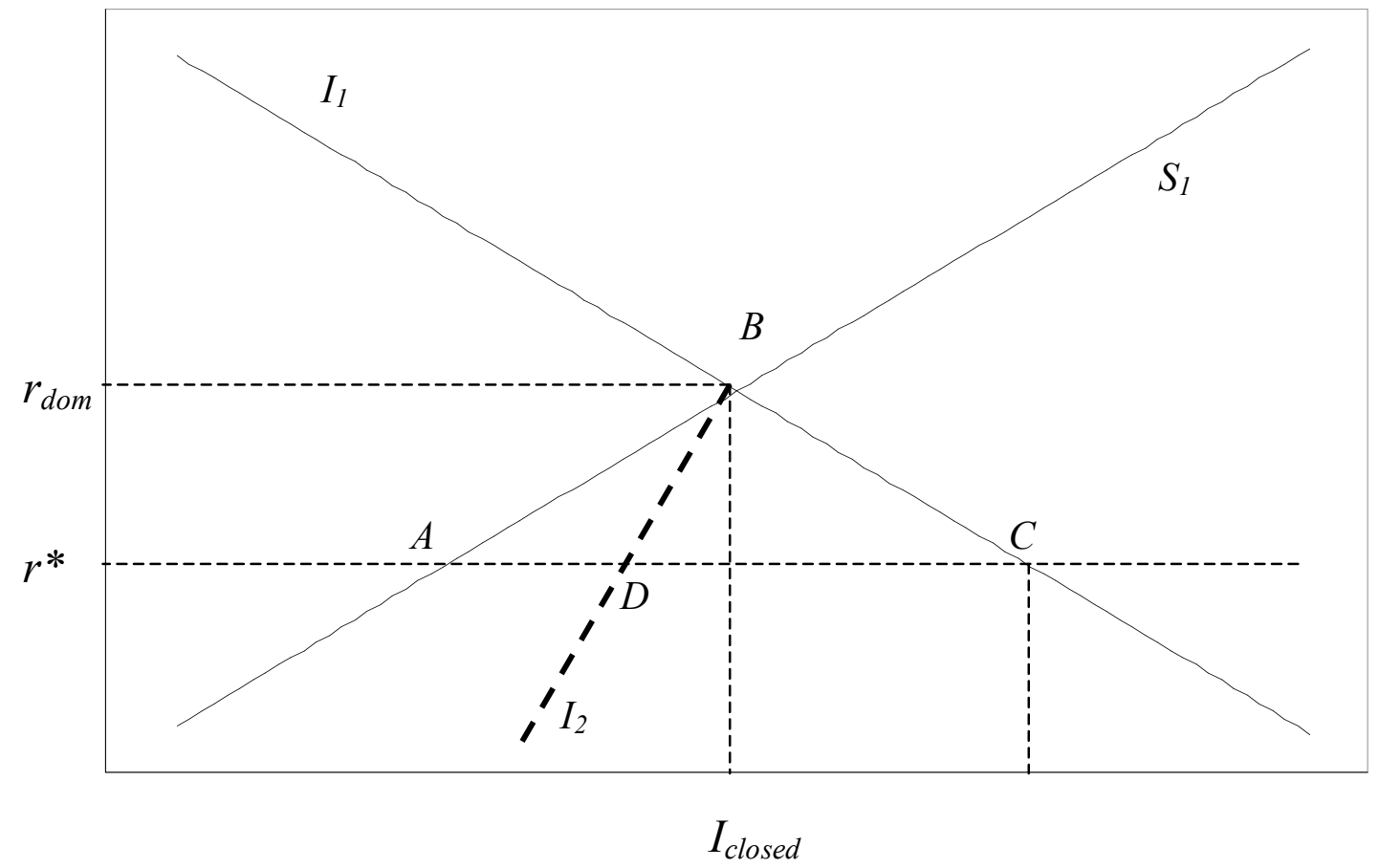

Investment, Saving

Source: Authors' model described in the text. 
Figure 11. Impact of an Exogenous Increase in Domestic Saving in an Economy Distorted by Foreign Capital Inflows

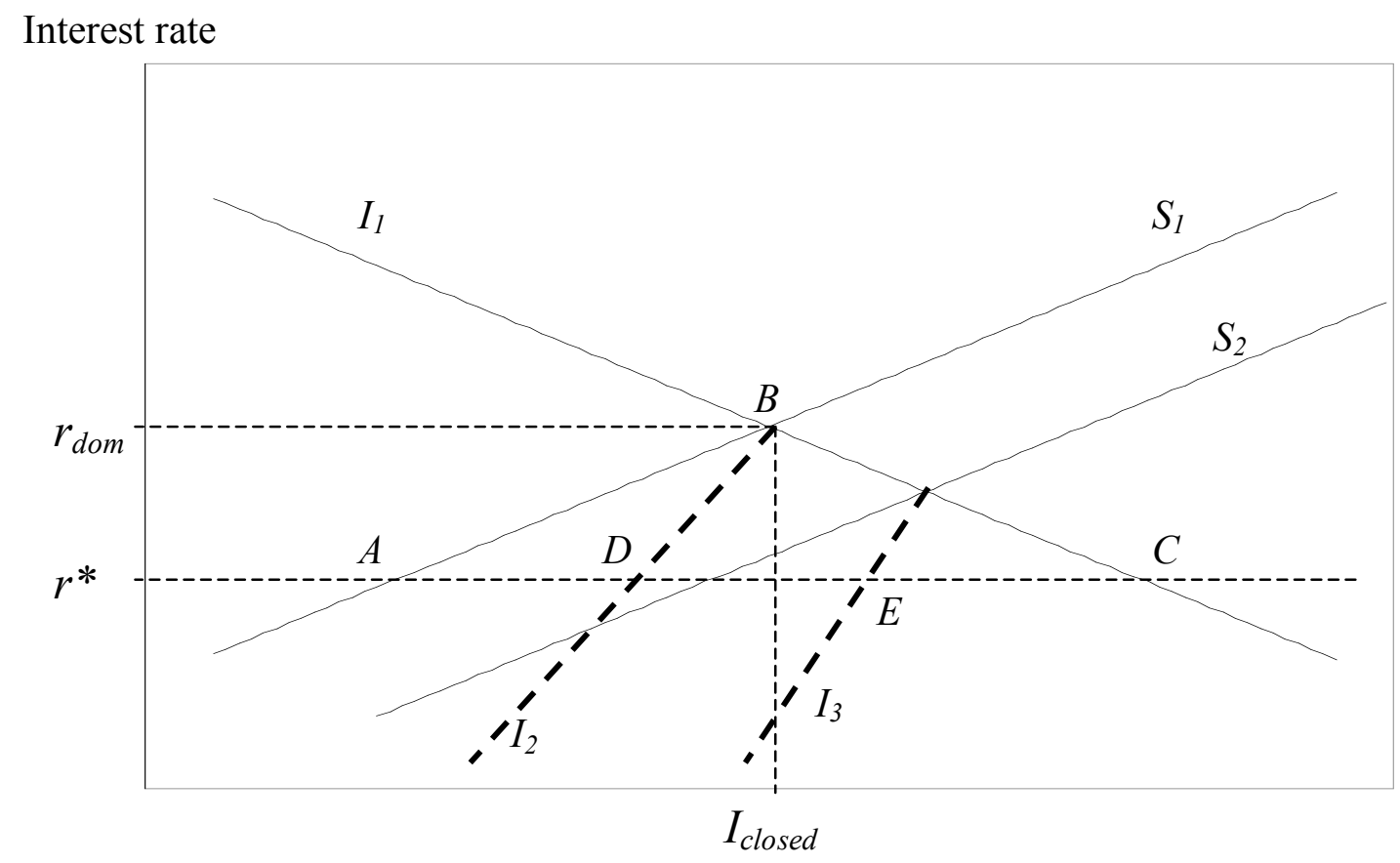

Investment, Saving

Source: Authors' model described in the text. 
Figure 12. Currency Overvaluation and Capital Flows, 1970-2004

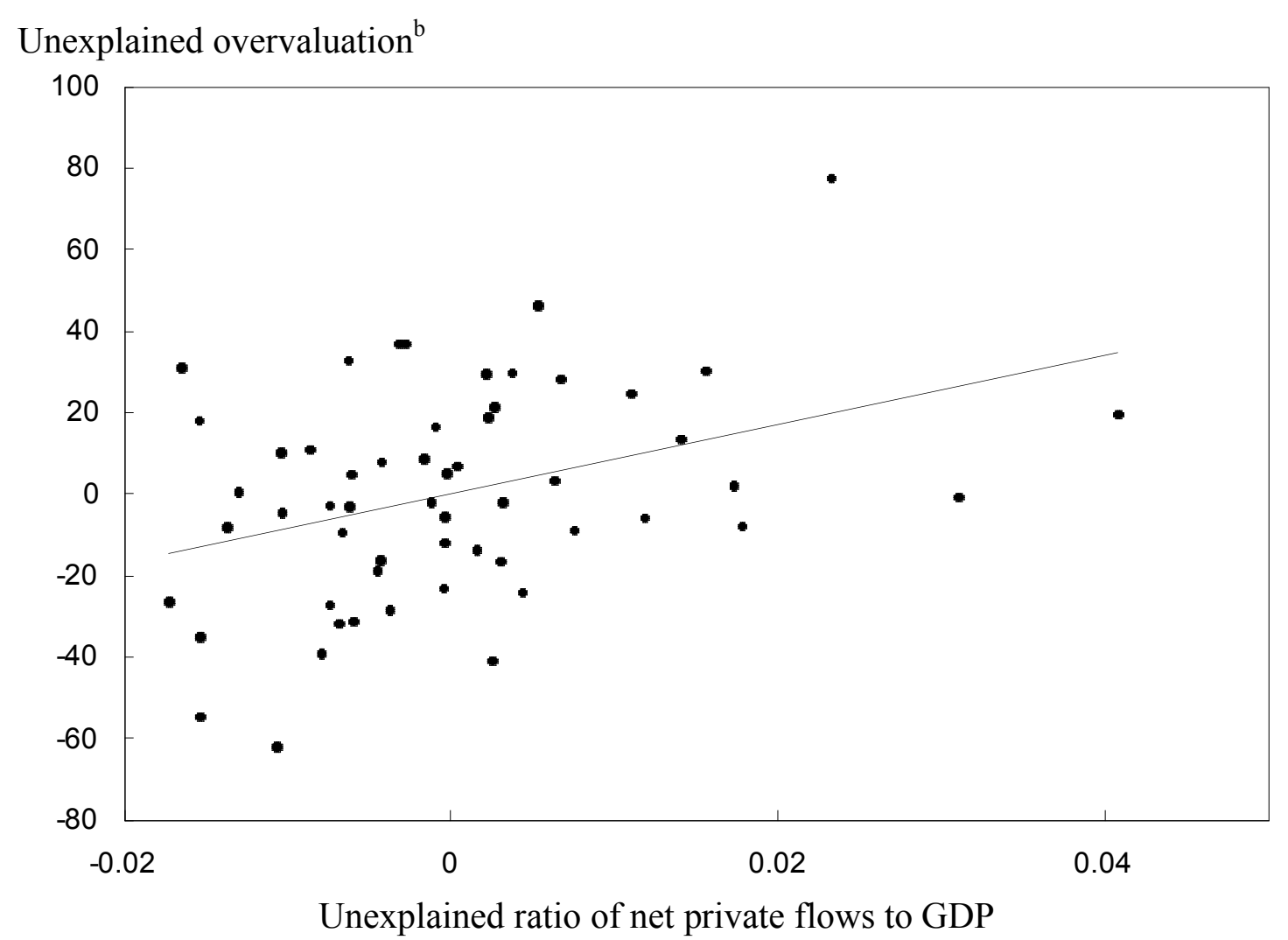

Source: World Bank, World Development Indicators; Lane and Milesi-Ferretti (2006); Johnson, Ostry, and Subramanian (2007); and authors' calculations.

a. The line plots the correlation between unexplained overvaluation and the unexplained ratio of net private inflows to GDP, defined below; this is the same as the conditional correlation obtained from regression 6-4 in table 6. Its slope is the coefficient on the ratio of net private flows to GDP (portfolio, equity, debt, and FDI) term in that regression. Data are for the fifty-six countries in the core sample.

b. Residuals from a regression of overvaluation on a constant and the working-age population. The unexplained component of the ratio of net private flows to GDP is defined analogously. 
Figure 13. Exchange Rate Overvaluation and Real Growth in GDP per Capita before and after Growth Spurts ${ }^{\mathrm{a}}$

\section{Sample of eleven countries}

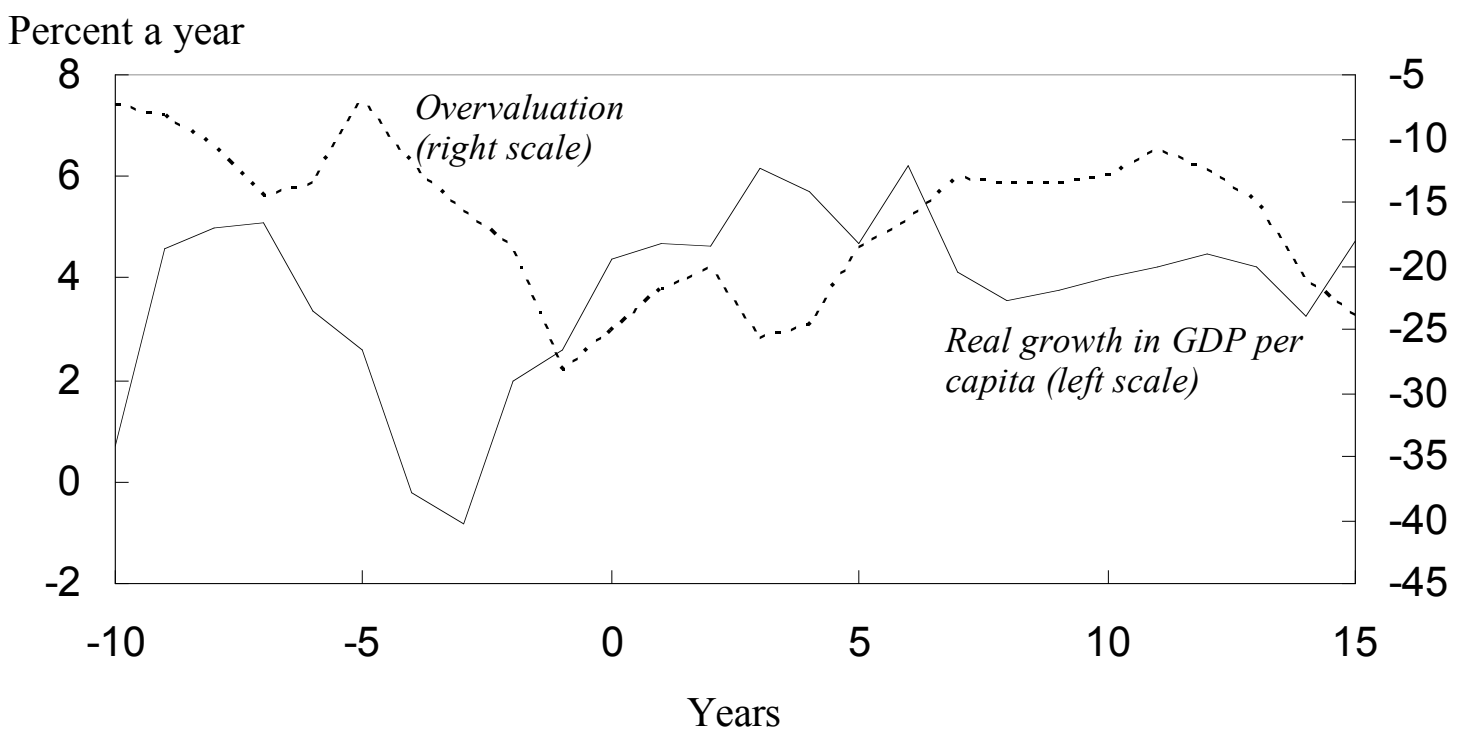

Sample of eight nonindustrial countries

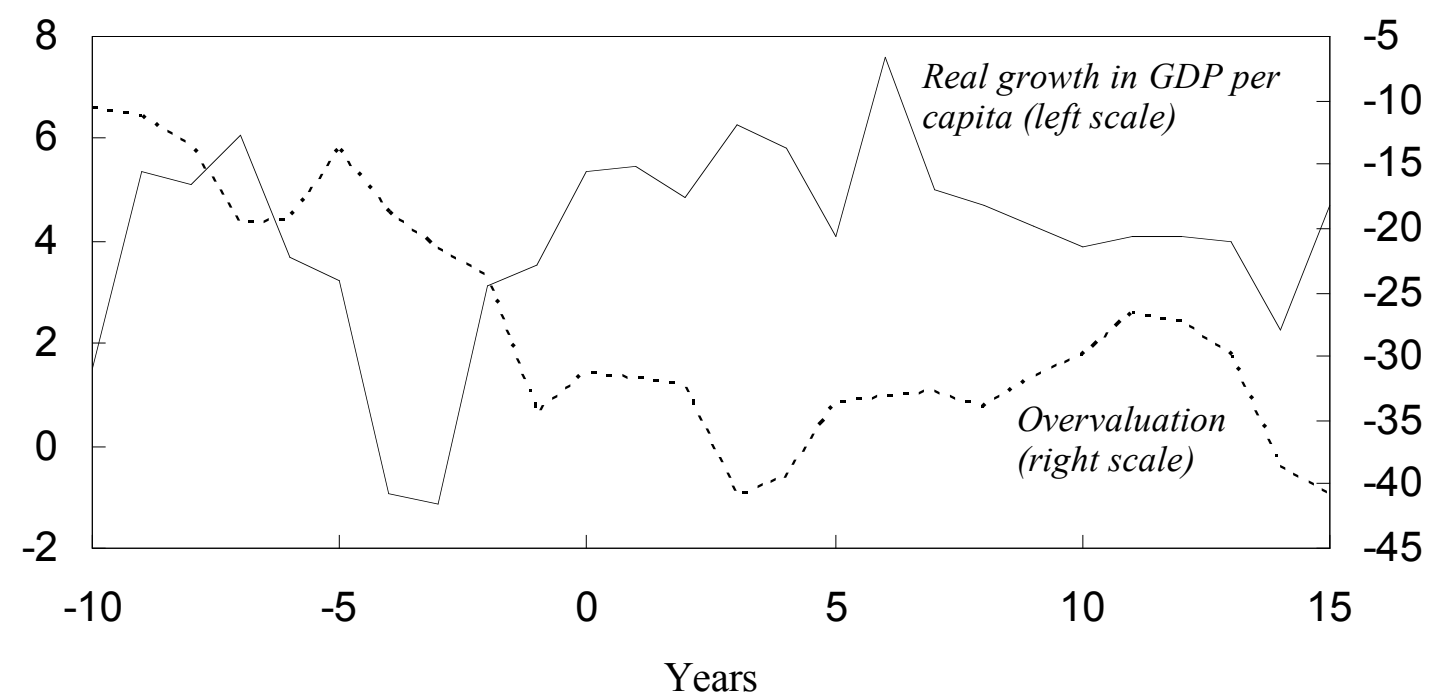

Source: Penn World Tables; Johnson, Ostry, and Subramanian (2007); and authors' calculations.

a. Simple averages of overvaluation and growth of GDP per capita. Countries and initial year (year 0) of their growth spurts are as in figure 8; bottom panel omits Ireland, Portual, and Spain. 
Table 1. Cross-Sectional OLS Regressions of Economic Growth Rates on the Current Account Balance

\begin{tabular}{|c|c|c|c|c|c|c|c|c|}
\hline \multirow[b]{2}{*}{ Independent variable } & \multicolumn{8}{|c|}{ Regression (dependent variable is average annual rate of growth of GDP per capita) ${ }^{\mathrm{a}}$} \\
\hline & $1-1$ & $1-2^{\mathrm{b}}$ & $1-3^{\mathrm{c}}$ & $1-4^{\mathrm{d}}$ & $1-5^{\mathrm{e}}$ & $1-6$ & $1-7$ & $1-8$ \\
\hline \multirow[t]{2}{*}{ Current account balance-GDP ratio } & 0.093 & 0.107 & 0.196 & 0.106 & & & 0.107 & -0.041 \\
\hline & $(0.036)^{* *}$ & $(0.056)^{*}$ & $(0.066)^{* * *}$ & $(0.057)^{*}$ & & & $(0.053)^{*}$ & $(0.085)$ \\
\hline \multirow[t]{2}{*}{ Log of initial GDP per capita } & -1.770 & -1.722 & -1.526 & -1.721 & -1.695 & -1.700 & -1.561 & -1.520 \\
\hline & $(0.242)^{* * *}$ & $(0.249)^{* * *}$ & $(0.256)^{* * *}$ & $(0.250)^{* * *}$ & $(0.287)^{* * *}$ & $(0.286)^{* * *}$ & $(0.266)^{* * *}$ & $(0.163)^{* * *}$ \\
\hline \multirow[t]{2}{*}{ Initial life expectancy } & 0.071 & 0.070 & 0.070 & 0.070 & 0.063 & 0.046 & 0.061 & 0.060 \\
\hline & $(0.026) * * *$ & $(0.026)^{* *}$ & $(0.027)^{* *}$ & $(0.026)^{* *}$ & $(0.030)^{* *}$ & $(0.031)$ & $(0.026)^{* *}$ & $(0.023) * *$ \\
\hline \multirow[t]{2}{*}{ Initial trade policy ${ }^{\mathrm{f}}$} & 0.987 & 1.016 & 1.702 & 1.013 & 1.009 & 0.897 & 0.718 & 0.564 \\
\hline & $(0.782)$ & $(0.817)$ & $(0.429)^{* * *}$ & $(0.819)$ & $(0.811)$ & $(0.836)$ & $(0.777)$ & $(0.814)$ \\
\hline \multirow[t]{2}{*}{ Fiscal balance-GDP ratio } & 0.044 & 0.048 & 0.028 & 0.049 & 0.049 & 0.042 & 0.037 & 0.040 \\
\hline & $(0.041)$ & $(0.043)$ & $(0.046)$ & $(0.043)$ & $(0.044)$ & $(0.045)$ & $(0.044)$ & $(0.041)$ \\
\hline \multirow[t]{2}{*}{ Institutional quality ${ }^{\mathrm{g}}$} & 5.759 & 5.568 & 4.981 & 5.589 & 5.921 & 6.474 & 4.469 & 4.121 \\
\hline & $(1.680)^{* * *}$ & $(1.677)^{* * *}$ & $(1.130)^{* * *}$ & $(1.686)^{* * *}$ & $(1.682)^{* * *}$ & $(1.669)^{* * *}$ & $(2.111)^{* *}$ & $(1.416)^{* * *}$ \\
\hline Net foreign assets-GDP ratio & & & & & $\begin{array}{c}0.005 \\
(0.005)\end{array}$ & & & \\
\hline Gross assets-GDP ratio & & & & & & $\begin{array}{c}0.013 \\
(0.007)^{*}\end{array}$ & & \\
\hline Gross liabilities-GDP ratio & & & & & & $\begin{array}{l}-0.007 \\
(0.005)\end{array}$ & & \\
\hline Investment-GDP ratio & & & & & & & $\begin{array}{c}0.074 \\
(0.050)\end{array}$ & \\
\hline Domestic saving-GDP ratio & & & & & & & & $\begin{array}{c}0.108 \\
(0.040)^{* * *}\end{array}$ \\
\hline No. of observations & 59 & 56 & 48 & 56 & 55 & 55 & 56 & 56 \\
\hline$R^{2}$ & 0.71 & 0.69 & 0.81 & 0.69 & 0.65 & 0.66 & 0.70 & 0.73 \\
\hline
\end{tabular}

Source: Authors' regressions using data from the World Bank, World Development Indicators; the Penn World Tables (version 6.2); Lane and Milesi-Ferretti (2006); Rajan and Subramanian (2005); and Bosworth and Collins (2003).

a. Data are period annual averages or initial-period observations for each of the fifty-six nonindustrial countries listed in appendix table A-1, from 1970 to 2004. All regressions include dummy variables equal to 1 for oil exporters and countries in sub-Saharan Africa. Numbers in parentheses are robust standard errors; asterisks indicate statistical significance at the $* * * 1, * * 5$, and $* 10$ percent level. GDP data are adjusted for international differences in purchasing power of the dollar.

b. Sample excludes three outliers: Nicaragua, Mozambique, and Singapore.

c. Sample excludes the above three outliers and all countries receiving foreign aid averaging more than 10 percent of their GDP.

d. Current account balance excludes foreign aid receipts.

e. In this regression and in regression 1-6, data on stock positions are not available for one country (Sierra Leone) in the core sample.

f. Measure of trade openness from Sachs and Warner (1995).

g. Measure of institutional quality from Hall and Jones (1999). 
Table 2. Cross-Sectional OLS Regressions of Growth Rates on the Current Account Balance Using Alternative Samples and Variables

\begin{tabular}{|c|c|c|c|c|}
\hline \multirow[b]{2}{*}{ Independent variable } & \multicolumn{4}{|c|}{$\begin{array}{l}\text { Regression (dependent variable is average annual rate of } \\
\text { growth of GDP per capita) }\end{array}$} \\
\hline & $2-1$ & $2-2$ & $2-3$ & $2-4$ \\
\hline Current account balance-GDP ratio & $\begin{array}{c}0.221 \\
(0.102)^{* *}\end{array}$ & $\begin{array}{c}0.105 \\
(0.051)^{* *}\end{array}$ & $\begin{array}{c}0.203 \\
(0.121)^{*}\end{array}$ & $\begin{array}{c}0.069 \\
(0.055)\end{array}$ \\
\hline Log of initial GDP per capita & $\begin{array}{c}-3.172 \\
(0.436)^{* * *}\end{array}$ & $\begin{array}{c}-1.795 \\
(0.210)^{* * *}\end{array}$ & $\begin{array}{c}-1.941 \\
(0.657)^{* * *}\end{array}$ & $\begin{array}{c}-1.644 \\
(0.207)^{* * *}\end{array}$ \\
\hline Initial life expectancy & $\begin{array}{c}0.191 \\
(0.059)^{* * *}\end{array}$ & $\begin{array}{c}0.078 \\
(0.023)^{* * *}\end{array}$ & $\begin{array}{c}0.175 \\
(0.060)^{* * *}\end{array}$ & $\begin{array}{c}0.048 \\
(0.029)^{*}\end{array}$ \\
\hline Initial trade policy ${ }^{\mathrm{b}}$ & $\begin{array}{l}1.391 \\
(0.800)^{*}\end{array}$ & $\begin{array}{l}1.036 \\
(0.579)^{*}\end{array}$ & $\begin{array}{c}0.538 \\
(0.437)\end{array}$ & $\begin{array}{c}0.679 \\
(0.573)\end{array}$ \\
\hline Fiscal balance-GDP ratio & $\begin{array}{c}0.102 \\
(0.091)\end{array}$ & $\begin{array}{c}0.035 \\
(0.031)\end{array}$ & $\begin{array}{c}0.122 \\
(0.071)^{*}\end{array}$ & $\begin{array}{c}0.051 \\
(0.041)\end{array}$ \\
\hline Institutional quality ${ }^{\mathrm{c}}$ & $\begin{array}{c}7.794 \\
(2.338)^{* * *}\end{array}$ & $\begin{array}{c}5.144 \\
(1.147)^{* * *}\end{array}$ & & $\begin{array}{c}2.812 \\
(1.348)^{* *}\end{array}$ \\
\hline Working-age share of total population & & & & $\begin{array}{c}0.194 \\
(0.072)\end{array}$ \\
\hline $\begin{array}{l}\text { Industrial country dummy } \times \text { current account } \\
\text { balance-GDP ratio }\end{array}$ & & $\begin{array}{c}-0.202 \\
(0.063)^{* * *}\end{array}$ & $\begin{array}{l}-0.234 \\
(0.115)^{* *}\end{array}$ & \\
\hline $\begin{array}{l}\text { Transition country dummy } \times \text { current account } \\
\text { balance-GDP ratio }\end{array}$ & & & $\begin{array}{c}-0.354 \\
(0.138)^{* *}\end{array}$ & \\
\hline Estimation period & $1985-97$ & $1970-2004$ & $1990-2004$ & 1970-2004 \\
\hline $\begin{array}{l}\text { No. of observations } \\
R^{2}\end{array}$ & $\begin{array}{c}56 \\
0.63\end{array}$ & $\begin{array}{c}78 \\
0.68\end{array}$ & $\begin{array}{c}99 \\
0.34\end{array}$ & $\begin{array}{c}56 \\
0.77\end{array}$ \\
\hline
\end{tabular}

Source: Authors' regressions using same source data as for table 1.

a. The sample in regressions 2-1 and 2-4 includes the fifty-six nonindustrial countries listed in appendix table A-1. The sample for regression 2-2 includes, in addition, the twenty-two industrial countries in that table, and regression 2-3 includes as well the twenty-one transition countries. All regressions include dummy variables equal to 1 for oil exporters and countries in sub-Saharan Africa. Numbers in parentheses are robust standard errors; asterisks indicate statistical significance at the ***1, **5, and $* 10$ percent level. GDP data are adjusted for international differences in purchasing power of the dollar.

b. Measure of trade openness from Sachs and Warner (1995).

c. Measure of institutional quality from Hall and Jones (1999). 
Table 3. Panel GMM Regressions of Economic Growth Rates on the Current Account Balance

\begin{tabular}{|c|c|c|c|c|c|c|c|c|}
\hline \multirow[b]{2}{*}{ Independent variable } & \multicolumn{7}{|c|}{ Regression (dependent variable is average annual rate of growth of GDP per capita) ${ }^{\mathrm{a}}$} & \multirow[b]{2}{*}{$3-8^{\mathrm{e}}$} \\
\hline & $3-1$ & $3-2^{\mathrm{b}}$ & $3-3^{\mathrm{c}}$ & $3-4^{\mathrm{d}}$ & $3-5$ & $3-6$ & $3-7$ & \\
\hline \multicolumn{9}{|l|}{ Current account balance-GDP } \\
\hline \multirow[t]{2}{*}{ ratio } & 0.100 & 0.127 & 0.251 & 0.130 & 0.166 & -0.001 & -0.009 & 0.086 \\
\hline & $(0.095)$ & $(0.112)$ & $(0.122)^{* *}$ & $(0.114)$ & $(0.124)$ & $(0.111)$ & $(0.093)$ & $(0.109)$ \\
\hline \multirow[t]{2}{*}{ Log of initial GDP per capita } & -1.977 & -1.540 & -2.868 & -1.838 & -0.766 & -0.682 & -1.506 & -1.246 \\
\hline & $(1.387)$ & $(1.264)$ & $(0.981)^{* * *}$ & $(1.341)$ & $(1.471)$ & $(1.407)$ & $(1.113)$ & $(1.407)$ \\
\hline \multirow[t]{2}{*}{ Initial life expectancy } & 0.057 & 0.050 & 0.094 & 0.072 & -0.023 & -0.034 & -0.028 & 0.059 \\
\hline & $(0.121)$ & $(0.107)$ & $(0.075)$ & $(0.124)$ & $(0.090)$ & $(0.094)$ & $(0.097)$ & $(0.116)$ \\
\hline \multirow{2}{*}{ Initial trade policy ${ }^{\mathrm{f}}$} & 2.580 & 2.108 & 2.161 & 2.220 & 2.132 & 2.285 & 1.283 & 1.350 \\
\hline & $(0.762)^{* * *}$ & $(0.911)^{* *}$ & $(0.837)^{* * *}$ & $(0.941)^{* *}$ & $(0.959)^{* *}$ & $(0.922)^{* *}$ & $(0.867)$ & $(0.797)^{*}$ \\
\hline \multirow[t]{2}{*}{ Fiscal balance-GDP ratio } & 0.167 & 0.188 & 0.094 & 0.182 & 0.097 & 0.208 & 0.126 & 0.147 \\
\hline & $(0.147)$ & $(0.161)$ & $(0.130)$ & $(0.136)$ & $(0.132)$ & $(0.222)$ & $(0.129)$ & $(0.087)^{*}$ \\
\hline \multirow[t]{2}{*}{ Institutional quality $^{g}$} & 16.825 & 15.182 & 17.136 & 14.561 & 1.562 & 5.331 & 8.475 & 10.462 \\
\hline & $(5.616)^{* * *}$ & $(5.790)^{* * *}$ & $(5.296)^{* * *}$ & $(5.912)^{* *}$ & $(4.415)$ & $(4.407)$ & $(5.610)$ & $(4.884)^{* *}$ \\
\hline Investment-GDP ratio & & & & & $\begin{array}{c}0.288 \\
(0.110)^{* * *}\end{array}$ & & & \\
\hline Saving-GDP ratio & & & & & & $\begin{array}{c}0.167 \\
(0.092)^{*}\end{array}$ & & \\
\hline \multirow{3}{*}{$\begin{array}{l}\text { Working-age share of total } \\
\text { population } \\
\text { Industrial country dummy } \times \\
\text { current account balance-GDP } \\
\text { ratio }\end{array}$} & & & & & & & $\begin{array}{c}0.296 \\
(0.158)^{*}\end{array}$ & \\
\hline & & & & & & & & -0.292 \\
\hline & & & & & & & & $(0.126)^{* *}$ \\
\hline \multirow{3}{*}{$\begin{array}{l}\text { Hansen test for over- } \\
\text { identifying restrictions (p- } \\
\text { value) } \\
\text { Arellano-Bond AR(2) test (p- } \\
\text { value) }\end{array}$} & 336 & 320 & 267 & 316 & 311 & 294 & 320 & 462 \\
\hline & 0.551 & 0.546 & 0.485 & 0.567 & 0.400 & 0.466 & 0.828 & 0.225 \\
\hline & 0.732 & 0.676 & 0.590 & 0.679 & 0.514 & 0.357 & 0.725 & 0.630 \\
\hline
\end{tabular}

a. Data are five-year averages or initial-period observations for each of the fifty-six nonindustrial countries listed in appendix table A-1, from 19702004 . All regressions include dummy variables equal to 1 for oil exporters and countries in sub-Saharan Africa. Numbers in parentheses are robust standard errors; asterisks indicate statistical significance at the $* * * 1, * * 5$, and *10 percent level. GDP data are adjusted for international differences in purchasing power of the dollar. All right-hand-side variables are treated as endogenous, and their third and fourth lags are used for instrumentation.

b. Sample excludes three outliers: Nicaragua, Mozambique, and Singapore.

c. Sample excludes the above three outliers and all countries receiving foreign aid averaging more than 10 percent of their GDP.

d. Current account balance excludes foreign aid receipts.

e. Regression also includes a dummy variable equal to 1 for industrial countries.

f. Measure of trade openness from Sachs and Warner (1995).

g. Measure of institutional quality from Hall and Jones (1999). 
Table 4. Cross-Sectional OLS Regressions of Growth in Value Added by Industry on Measures of FDI and Financial Dependence

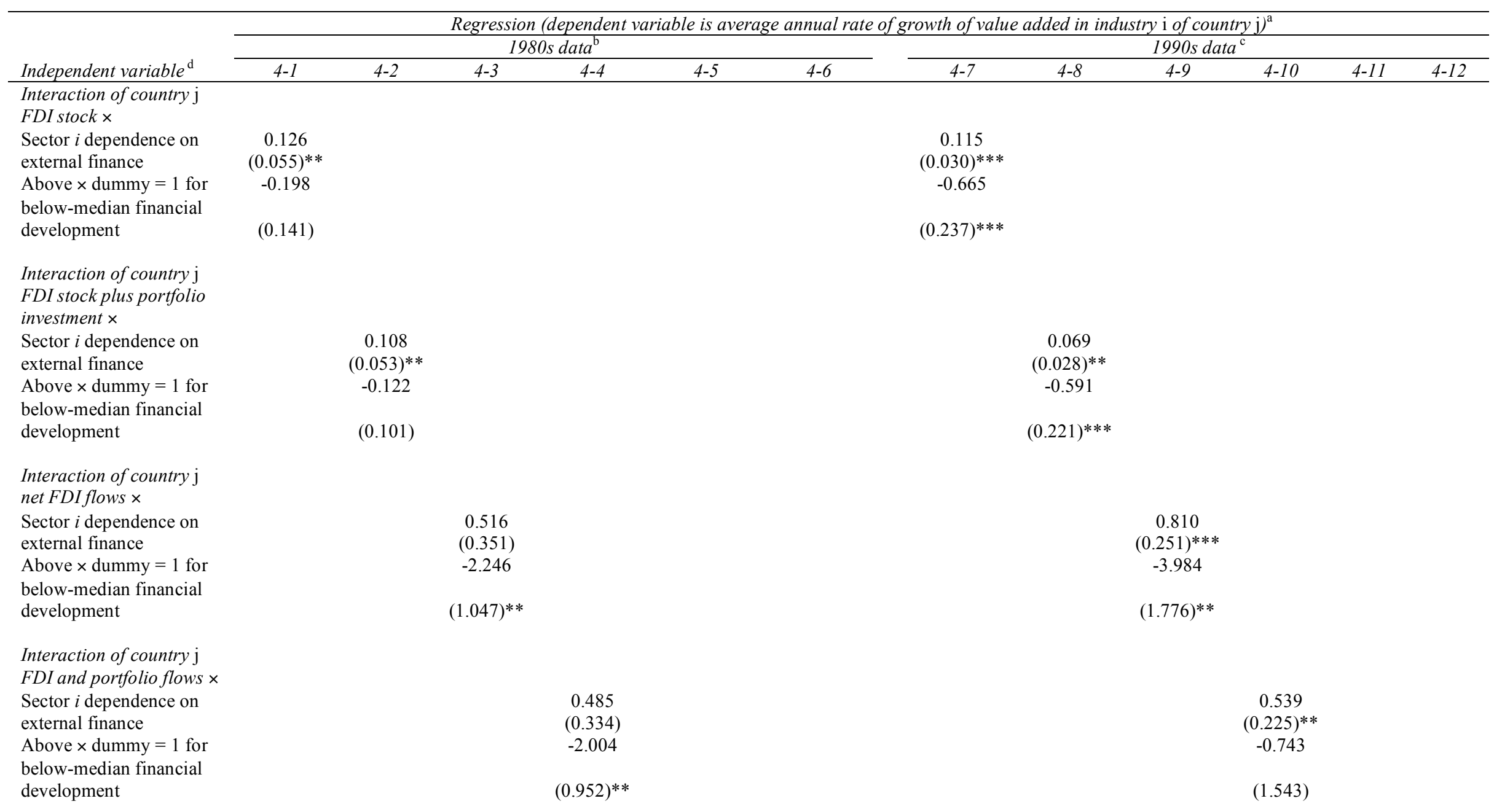




\section{Table 4. Cross-Sectional OLS Regressions of Growth in Value Added by Industry on Measures of FDI and Financial}

Dependence (Continued)

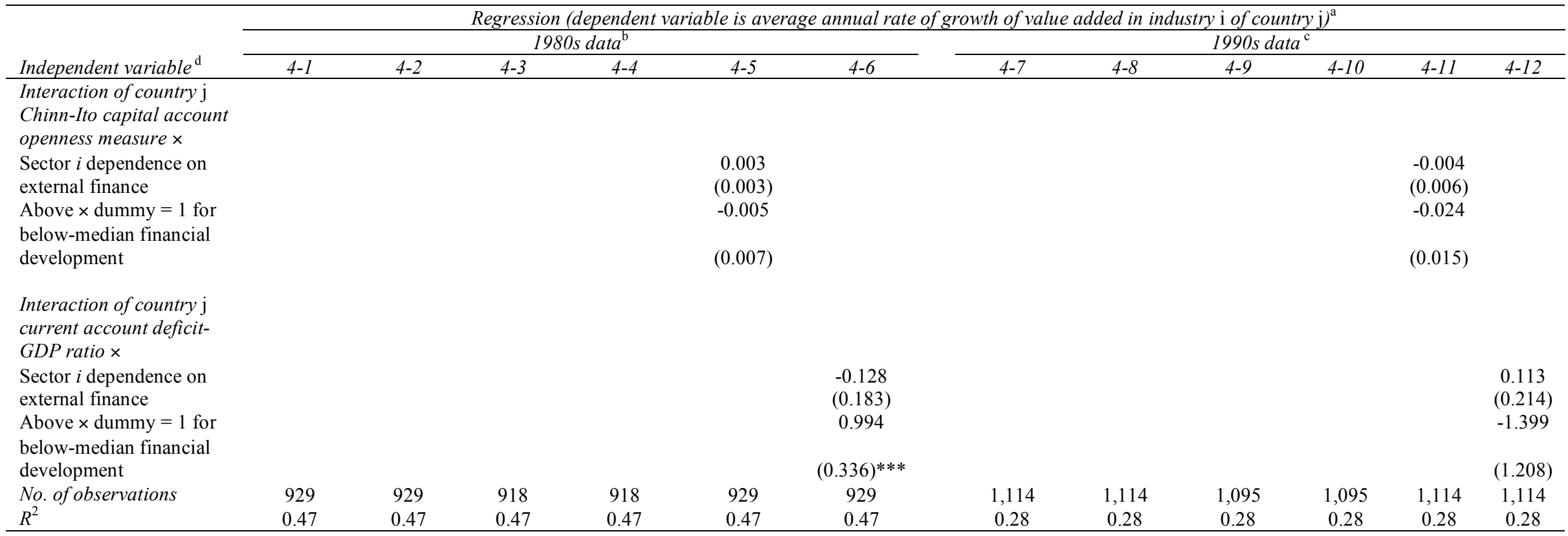

Source: Authors' regressions using data from the United Nations Industrial Development Organization.

a. Data are period averages for individual industries. All estimations include country and industry fixed effects, the initial share of a sector's value added in total value added for that country, and two measures of domestic financial development: the country's ratio of domestic credit to GDP and its index of corporate governance (De Nicolo and others, 2006). The data differ from those in Rajan and Zingales (1998) for the 1980s and those of Laeven and others (2006) for the 1990s in that Nigeria was dropped because of data errors, and the index of corporate governance was available only for a subset of countries.

b. Includes thirty-four industrial and nonindustrial countries in the UNIDO database.

c. Includes thirty-seven industrial and nonindustrial countries in the UNIDO database.

d. FDI, portfolio investment, and current account balance are measured as ratios to GDP. 
Table 5. Panel OLS Regressions of Growth in Value Added by Industry on Measures of FDI and Financial Dependence

\begin{tabular}{|c|c|c|c|c|c|c|}
\hline \multirow[b]{2}{*}{ Independent variable ${ }^{\mathrm{b}}$} & \multicolumn{6}{|c|}{$\begin{array}{c}\text { Regression (dependent variable is average annual rate of growth of value added sector } \mathrm{i} \\
\text { of country } \mathrm{j} \text { ) }\end{array}$} \\
\hline & $5-1$ & $5-2$ & $5-3$ & $5-4$ & $5-5$ & $5-6$ \\
\hline \multicolumn{7}{|l|}{ Interaction of country $\mathrm{j}$ FDI stock $\times$} \\
\hline $\begin{array}{l}\text { Sector } i \text { dependence on external } \\
\text { finance }\end{array}$ & $\begin{array}{c}-0.122 \\
(0.051)^{* *}\end{array}$ & & & & & \\
\hline $\begin{array}{l}\text { Above } \times \text { dummy }=1 \text { for below-median } \\
\text { financial development }\end{array}$ & $\begin{array}{c}-0.320 \\
(0.057)^{* * *}\end{array}$ & & & & & \\
\hline \multicolumn{7}{|l|}{$\begin{array}{l}\text { Interaction of country } \mathrm{j} \text { FDI stock plus } \\
\text { portfolio investment } \times\end{array}$} \\
\hline $\begin{array}{l}\text { Sector } i \text { dependence on external } \\
\text { finance }\end{array}$ & & $\begin{array}{l}-0.065 \\
(0.024)^{* *}\end{array}$ & & & & \\
\hline $\begin{array}{l}\text { Above } \times \text { dummy }=1 \text { for below-median } \\
\text { financial development }\end{array}$ & & $\begin{array}{c}-0.269 \\
(0.058)^{* * *}\end{array}$ & & & & \\
\hline \multicolumn{7}{|l|}{ Interaction of country $\mathrm{j}$ net FDI flows $\times$} \\
\hline $\begin{array}{l}\text { Sector } i \text { dependence on external } \\
\text { finance }\end{array}$ & & & $\begin{array}{c}-0.903 \\
(0.209)^{* * *}\end{array}$ & & & \\
\hline $\begin{array}{l}\text { Above } \times \text { dummy }=1 \text { for below-median } \\
\text { financial development }\end{array}$ & & & $\begin{array}{c}-2.838 \\
(0.338)^{* * *}\end{array}$ & & & \\
\hline \multicolumn{7}{|l|}{$\begin{array}{l}\text { Interaction of country } \mathrm{j} \text { FDI and } \\
\text { portfolio flows } \times\end{array}$} \\
\hline $\begin{array}{l}\text { Sector } i \text { dependence on external } \\
\text { finance }\end{array}$ & & & & $\begin{array}{l}-0.569 \\
(0.120) * * *\end{array}$ & & \\
\hline $\begin{array}{l}\text { Above } \times \text { dummy }=1 \text { for below-median } \\
\text { financial development }\end{array}$ & & & & $\begin{array}{c}-2.166 \\
(0.378)^{* * *}\end{array}$ & & \\
\hline \multicolumn{7}{|l|}{ Interaction of country $\mathrm{j}$ Chinn-Ito } \\
\hline $\begin{array}{l}\text { Sector } i \text { dependence on external } \\
\text { finance }\end{array}$ & & & & & $\begin{array}{c}0.011 \\
(0.004)^{* * *}\end{array}$ & \\
\hline $\begin{array}{l}\text { Above } \times \text { dummy }=1 \text { for below-median } \\
\text { financial development }\end{array}$ & & & & & $\begin{array}{c}-0.020 \\
(0.007)^{* * *}\end{array}$ & \\
\hline
\end{tabular}


Table 5. Panel OLS Regressions of Growth in Value Added by Industry on Measures of FDI and Financial Dependence (Continued)

\begin{tabular}{|c|c|c|c|c|c|c|}
\hline \multirow[b]{2}{*}{ Independent variable } & \multicolumn{6}{|c|}{$\begin{array}{c}\text { Regression (dependent variable is average annual rate of growth of value added sector } \mathrm{i} \\
\text { of country })^{\mathrm{a}}\end{array}$} \\
\hline & $5-1$ & $5-2$ & $5-3$ & $5-4$ & $5-5$ & $5-6$ \\
\hline \multicolumn{7}{|l|}{$\begin{array}{l}\text { Interaction of country } \mathrm{j} \text { current } \\
\text { account deficit-GDP ratio } \times\end{array}$} \\
\hline $\begin{array}{l}\text { Sector } i \text { dependence on external } \\
\text { finance }\end{array}$ & & & & & & $\begin{array}{c}-0.240 \\
(0.085)^{* * *}\end{array}$ \\
\hline $\begin{array}{l}\text { Above } \times \text { dummy }=1 \text { for below-median } \\
\text { financial development }\end{array}$ & & & & & & $\begin{array}{l}-0.380 \\
(0.286)\end{array}$ \\
\hline No. of observations & 2922 & 2922 & 2882 & 2882 & 2914 & 2922 \\
\hline$R^{2}$ & 0.74 & 0.74 & 0.74 & 0.74 & 0.74 & 0.74 \\
\hline
\end{tabular}

Source: Authors' regressions using same source data as for table 4.

a. Data are period averages for individual industries. All estimations include country and industry fixed effects and country-industry fixed effects. Data are from the UNIDO database and cover fifty-two industrial and nonindustrial countries. The data differ from those in Rajan and Zingales (1998) for the 1980s and Laeven and others (2006) for the 1990s only in that Nigeria was dropped because of data errors. Numbers in parentheses are robust standard errors; asterisks indicate statistical significance at the $* * * 1, * * 5$, and $* 10$ percent level. GDP data are adjusted for international differences in purchasing power of the dollar

b. FDI, portfolio investment, and current account balance are measured as ratios to GDP. 
Table 6. Cross-Sectional OLS Regressions of Overvaluation on Capital Stock and Flow Measures

\begin{tabular}{|c|c|c|c|c|c|c|c|c|}
\hline \multirow[b]{2}{*}{ Independent variable } & \multicolumn{8}{|c|}{ Regression (dependent variable is the degree of real overvaluation of the national currency) } \\
\hline & $6-1$ & $6-2^{\mathrm{b}}$ & $6-3$ & $6-4$ & $6-5$ & $6-6$ & $6-7^{\mathrm{c}}$ & $6-8$ \\
\hline \multirow[t]{2}{*}{ Working-age share of total population } & -1.66 & -1.66 & -2.30 & -3.02 & -2.53 & -2.11 & -2.47 & -2.88 \\
\hline & $(0.88)^{*}$ & $(1.05)$ & $(0.91)^{* *}$ & $(0.98)^{* * *}$ & $(0.96)^{* *}$ & $(0.86)^{* *}$ & $(0.93)^{* * *}$ & $(0.94)^{* * *}$ \\
\hline \multirow[t]{2}{*}{ Net liabilities-GDP ratio ${ }^{\mathrm{d}}$} & 19.46 & 10.79 & & & & & & \\
\hline & $(11.20)^{*}$ & $(14.74)$ & & & & & & \\
\hline \multirow[t]{2}{*}{ Net FDI liabilities-GDP ratio } & & & 30.90 & & & & & \\
\hline & & & $(23.48)$ & & & & & \\
\hline \multirow[t]{2}{*}{ Net private inflows-GDP ratio ${ }^{e}$} & & & & 843.69 & & & & 825.88 \\
\hline & & & & $(327.58)^{* *}$ & & & & $(326.25)^{* *}$ \\
\hline \multirow[t]{2}{*}{ Net FDI flows-GDP ratio } & & & & & 675.57 & & 670.13 & \\
\hline & & & & & $(355.73)^{*}$ & & $(354.93)^{*}$ & \\
\hline \multirow[t]{2}{*}{ Chinn-Ito capital account openness measure } & & & & & & -1.92 & & \\
\hline & & & & & & $(3.85)$ & & \\
\hline Industrial country dummy $\times$ net FDI flows-GDP & & & & & & & $-1,091.39$ & \\
\hline ratio & & & & & & & $(444.68)^{* *}$ & \\
\hline Industrial country dummy $\times$ net private flows- & & & & & & & & $-1,038.02$ \\
\hline GDP ratio & & & & & & & & $(349.32)^{* * *}$ \\
\hline No. of observations & 55 & 48 & 55 & 56 & 56 & 55 & 78 & 78 \\
\hline$R^{2}$ & 0.15 & 0.09 & 0.14 & 0.24 & 0.18 & 0.12 & 0.46 & 0.49 \\
\hline
\end{tabular}

Source: Authors' regressions using same source data as tables 1 and 4 and authors' calculations based on Johnson, Ostry, and Subramanian (2007).

a. The dependent variable is overvaluation, measured as described in the text. Except as noted below, data are period annual averages for each of the fifty-six nonindustrial countries listed in appendix table A-1, from 1970 to 2004 . Numbers in parentheses are robust standard errors; asterisks indicate statistical significance at the ***1, $* * 5$, and $* 10$ percent level.

b. Sample omits countries receiving foreign aid averaging more than 10 percent of their GDP.

c. This regression and regression 6-8 include a dummy variable for industrial countries (coefficients not shown).

d. Net liabilities are gross liabilities minus assets; Sierra Leone is excluded from the sample because data are unavailable.

e. Net private inflows are gross private inflows (FDI plus portfolio equity flows plus portfolio debt flows) minus outflows. 
Table 7. Cross-Sectional and Panel OLS Regressions of GDP Growth Rates on Real Overvaluation

\begin{tabular}{|c|c|c|c|c|c|c|c|c|c|}
\hline \multirow[b]{3}{*}{ Independent variable } & \multicolumn{9}{|c|}{ Regression (dependent variable is average annual rate of GDP growth) } \\
\hline & \multicolumn{4}{|c|}{ Cross-sectional $^{\mathrm{b}}$} & \multicolumn{5}{|c|}{ Panel $^{\mathrm{c}}$} \\
\hline & $7-1$ & $7-2^{\mathrm{d}}$ & $7-3^{\mathrm{e}}$ & $7-4$ & $7-5$ & $7-6$ & $7-7$ & $7-8$ & $7-9$ \\
\hline Current account balance-GDP ratio & $\begin{array}{c}0.091 \\
(0.040)^{* *}\end{array}$ & $\begin{array}{c}0.086 \\
(0.058)\end{array}$ & $\begin{array}{c}0.185 \\
(0.066)^{* * *}\end{array}$ & $\begin{array}{c}0.061 \\
(0.055)\end{array}$ & $\begin{array}{c}0.035 \\
(0.086)\end{array}$ & $\begin{array}{l}-0.004 \\
(0.159)\end{array}$ & $\begin{array}{c}0.181 \\
(0.148)\end{array}$ & $\begin{array}{l}-0.049 \\
(0.132)\end{array}$ & $\begin{array}{c}0.011 \\
(0.106)\end{array}$ \\
\hline Working-age share of total population & & & & $\begin{array}{c}0.181 \\
(0.072)^{* *}\end{array}$ & & & & $\begin{array}{l}0.143 \\
(0.156)\end{array}$ & \\
\hline Degree of overvaluation ${ }^{\mathrm{f}}$ & $\begin{array}{c}-0.010 \\
(0.005)^{*}\end{array}$ & $\begin{array}{c}-0.011 \\
(0.006)^{*}\end{array}$ & $\begin{array}{l}-0.006 \\
(0.004)\end{array}$ & $\begin{array}{l}-0.005 \\
(0.004)\end{array}$ & $\begin{array}{c}-0.039 \\
(0.017)^{* *}\end{array}$ & $\begin{array}{l}-0.037 \\
(0.024)\end{array}$ & $\begin{array}{l}-0.022 \\
(0.014)\end{array}$ & $\begin{array}{c}-0.038 \\
(0.015)^{* * *}\end{array}$ & \\
\hline $\begin{array}{l}\text { Degree of overvaluation } \times \text { dummy for } \\
\text { overvaluation }>0\end{array}$ & & & & & & & & & $\begin{array}{l}-0.044 \\
(0.025)^{*} \\
-0.021\end{array}$ \\
\hline $\begin{array}{l}\text { Degree of overvaluation } \times \text { dummy for } \\
\text { overvaluation }<0\end{array}$ & & & & & & & & & $(0.026)$ \\
\hline No. of observations & 59 & 56 & 48 & 56 & 336 & 320 & 267 & 320 & 320 \\
\hline & 0.73 & 0.71 & 0.82 & 0.78 & & & & & \\
\hline $\begin{array}{l}\text { Hansen test for overidentifying } \\
\text { restrictions ( } p \text {-value) }\end{array}$ & & & & & 0.741 & 0.802 & 0.757 & 0.975 & 0.912 \\
\hline Arellano-Bond AR(2) test (p-value) & & & & & 0.602 & 0.537 & 0.652 & 0.509 & 0.529 \\
\hline
\end{tabular}

Source: Authors' regressions using same source data as for table 6.

a. Data are period averages of annual data for each of the fifty-six nonindustrial countries listed in appendix table A-1, from 1970 to 2004 . Numbers in parentheses are robust standard errors; asterisks indicate statistical significance at the $* * * 1, * * 5$, and $* 10$ percent level. GDP data are adjusted for international differences in purchasing power of the dollar. Covariates are as in tables 1, 2, and 3 and are omitted for presentational simplicity.

b. All regressions include dummy variables for oil exporters and for sub-Saharan Africa.

c. The sample period is split into five-year subperiods. All right-hand-side variables are treated as exogenous, and the third and fourth lags are used for instrumentation.

d. In this regression and regression 7-4, 7-6, 7-8, and 7-9, sample omits Mozambique, Nicaragua, and Singapore.

e. In this regression and regression 7-7, sample omits countries receiving aid averaging more than 10 percent of their GDP.

f. Measured as described in the text. 
Table 8. OLS Regressions of Industry Growth in Value Added on Real Overvaluation Interacted with Sector Exportability

\begin{tabular}{|c|c|c|c|c|c|c|c|c|c|}
\hline \multirow[b]{3}{*}{ Independent variable } & \multicolumn{9}{|c|}{ Regression (dependent variable is annual average rate of growth of value added in sector $\mathrm{i}$ of country $\mathrm{j}$ ) } \\
\hline & \multicolumn{3}{|c|}{$1980 \mathrm{~s}$} & \multicolumn{3}{|c|}{$1990 \mathrm{~s}$} & \multicolumn{3}{|c|}{ Pooled } \\
\hline & $8-1$ & $8-2$ & $8-3$ & $8-4$ & $8-5$ & $8-6$ & $8-7$ & $8-8$ & $8-9$ \\
\hline $\begin{array}{l}\text { Country } \mathrm{j} \text { degree of overvaluation } \times \\
\text { sector } i \text { exportability measure } 1^{\mathrm{b}}\end{array}$ & $\begin{array}{c}-0.0006 \\
(0.0003)^{* *}\end{array}$ & & & $\begin{array}{c}-0.0006 \\
(0.0003)^{* *}\end{array}$ & & & $\begin{array}{c}-0.0002 * * \\
(0.0001)\end{array}$ & & \\
\hline $\begin{array}{l}\text { Country j degree of overvaluation } \times \\
\text { sector } i \text { exportability measure } 2^{\mathrm{c}}\end{array}$ & & $\begin{array}{c}-0.0012 \\
(0.0006)^{* *}\end{array}$ & & & $\begin{array}{l}-0.0006 \\
(0.0003)^{*}\end{array}$ & & & $\begin{array}{l}-0.0008 \\
(0.0003)^{* *}\end{array}$ & \\
\hline $\begin{array}{l}\text { Country j degree of overvaluation } \times \\
\text { sector } i \text { exportability measure } 3^{\mathrm{d}}\end{array}$ & & & $\begin{array}{l}-0.0013 \\
(0.0010)\end{array}$ & & & $\begin{array}{l}-0.0009 \\
(0.0005)^{*}\end{array}$ & & & $\begin{array}{c}-0.0010 \\
(0.0005)^{* *}\end{array}$ \\
\hline No. of observations & 619 & 619 & 619 & 751 & 751 & 751 & 1,370 & 1,370 & 1,370 \\
\hline$R^{2}$ & 0.37 & 0.37 & 0.37 & 0.25 & 0.24 & 0.24 & 0.20 & 0.21 & 0.21 \\
\hline
\end{tabular}

Source: Authors' regressions using calculations based on Johnson, Ostry, and Subramanian (2007) and United Nations Industrial Development Organization (UNIDO).

a. Data are period averages for each of the thirty nonindustrial countries listed in appendix table A-1 for which data are available from UNIDO. All regressions include country and industry fixed effects and the initial industry share of value added in economy-wide value added. Numbers in parentheses are robust standard errors; asterisks indicate statistical significance at the $* * * 1, * * 5$, and $* 10$ percent level.

b. Exportable industries are those for which the ratio of exports to value added, averaged across all countries in the group, is above the median.

c. Exportable industries are defined as the textiles, clothing, leather, and footwear industries only.

d. Exportable industries are defined as the textiles and clothing industries only. 


\section{Table A-1. Country Samples}

\begin{tabular}{|c|c|c|c|}
\hline Industrial & Transition & \multicolumn{2}{|c|}{ Nonindustrial, nontransition } \\
\hline Australia & Albania & Algeria & Mali \\
\hline Austria & Armenia & Argentina & Mauritius \\
\hline Belgium & Belarus & Bolivia & Mexico \\
\hline Canada & Bosnia & \& Brazil & Morocco \\
\hline Denmark & Herzegovina & Cameroon & Mozambique \\
\hline Finland & Bulgaria & Chile & Nicaragua \\
\hline France & Croatia & China & Nigeria \\
\hline Germany & Czech Rep. & Colombia & Pakistan \\
\hline Greece & Estonia & Costa Rica & Panama \\
\hline Iceland & Georgia & Côte d'Ivoire & Paraguay \\
\hline Ireland & Hungary & Cyprus & Peru \\
\hline Italy & Kazakhstan & Dominican Rep. & Philippines \\
\hline Japan & Kyrgyz Rep. & Ecuador & Rwanda \\
\hline Netherlands & Latvia & Egypt & Senegal \\
\hline New Zealand & Lithuania & El Salvador & Sierra Leone \\
\hline Norway & Moldova & Ethiopia & Singapore \\
\hline Portugal & Poland & Ghana & South Africa \\
\hline Spain & Romania & Guatemala & Sri Lanka \\
\hline Sweden & Russia & Haiti & Tanzania \\
\hline Switzerland & Slovak Rep. & Honduras & Thailand \\
\hline United Kingdom & Slovenia & India & Trinidad \& Tobago \\
\hline United States & Ukraine & Indonesia & Tunisia \\
\hline & & Iran & Turkey \\
\hline & & Israel & Uganda \\
\hline & & Jamaica & Uruguay \\
\hline & & Jordan & Venezuela \\
\hline & & Kenya & Zambia \\
\hline & & Korea & Zimbabwe \\
\hline & & Madagascar & \\
\hline & & Malawi & \\
\hline & & Malaysia & \\
\hline
\end{tabular}


Table A-2. Growth and Alternative Measures of Financial Integration ${ }^{a}$

\begin{tabular}{|c|c|c|c|c|}
\hline \multirow[b]{2}{*}{ Independent variable } & \multicolumn{4}{|c|}{ Regression } \\
\hline & $A-2-1$ & $A-2-2$ & $A-2-3$ & $A-2-4$ \\
\hline \multirow[t]{2}{*}{ Log of initial per capita GDP } & -1.712 & -1.746 & -1.780 & -1.665 \\
\hline & $(0.328)^{* * *}$ & $(0.284)^{* * *}$ & $(0.295)^{* *}$ & $*(0.340) * * *$ \\
\hline \multirow[t]{2}{*}{ Initial life expectancy } & 0.052 & 0.069 & 0.063 & 0.067 \\
\hline & $(0.032)$ & $(0.029)^{* *}$ & $(0.032)^{*}$ & $(0.030)^{* *}$ \\
\hline \multirow[t]{2}{*}{ Initial trade policy ${ }^{\mathrm{b}}$} & 1.127 & 0.994 & 0.965 & 1.160 \\
\hline & $(0.808)$ & $(0.824)$ & $(0.826)$ & $(0.969)$ \\
\hline \multirow[t]{2}{*}{ Ratio of fiscal balance to GDP } & 0.057 & 0.068 & 0.066 & 0.058 \\
\hline & $(0.047)$ & $(0.045)$ & $(0.045)$ & $(0.044)$ \\
\hline \multirow{2}{*}{ Institutional quality $^{\mathrm{c}}$} & 6.375 & 6.269 & 6.220 & 5.675 \\
\hline & $(1.692)^{* * *}$ & $(1.729)^{* * *}$ & $(1.648)^{* *}$ & * $(2.144)^{* *}$ \\
\hline \multirow[t]{2}{*}{ FDI liabilities-GDP ratio } & 1.524 & & & \\
\hline & $(0.924)$ & & & \\
\hline \multirow[t]{2}{*}{ Net FDI flows-GDP ratio } & & 10.374 & & \\
\hline & & $(12.223)$ & & \\
\hline \multirow[t]{2}{*}{ Ratio of gross private inflows $(\mathrm{FDI}+$ portfolio + debt) to GDP } & & & 12.688 & \\
\hline & & & $(10.007)$ & \\
\hline \multirow[t]{2}{*}{ Capital account policy openness ${ }^{\mathrm{d}}$} & & & & -0.098 \\
\hline & & & & $(0.203)$ \\
\hline No. of observations & 55 & 56 & 56 & 55 \\
\hline$R^{2}$ & 0.66 & 0.67 & 0.68 & 0.65 \\
\hline
\end{tabular}

Source: Authors' regressions using same source data as for tables 1, 2, and 4.

a. The dependent variable is annual average growth in GDP per capita, 1970-2004.

b. Measure of trade openness from Sachs and Warner (1995).

c. Measure of institutional quality from Hall and Jones (1999).

d. Measure of capital account policy openness from Chinn and Ito (2006). 